\title{
PERANAN KEBIJAKAN NILAI TUKAR DALAM ERA DEREGULASI DAN GLOBALISASI
}

\section{Doddy Budi Waluyo dan Benny Siswanto *)}

Ultimate target kebijakan moneter di Indonesia diantaranya adalah kestabilan harga dan kemantapan neraca pembayaran. Untuk mencapai tujuan tersebut, selama ini kebijakan nilai tukar Rupiah selalu diarahkan untuk menjaga keseimbangan internal dan eksternal, atau dengan kata lain, nilai tukar digunakan sekaligus sebagai alat moneter (kestabilan harga) dan alat daya saing (mendorong ekspor).

Penelitian ini dilakukan untuk mengetahui hubungan antara nilai tukar dengan keseimbangan internal (yang diwakili oleh inflasi) dan keseimbangan eksternal (yang diwakili oleh ekspor dan impor nonmigas), serta sekaligus juga untuk mengetahui seberapa besar efektifitas penetapan nilai tukar mencapai keseimbangan dalam periode 1983-1997 dan menelaah volatilitas nilai tukar rupiah setelah dilepas ke mekanisme pasar (free floating). Pengujian dilakukan dengan menggunakan test kausalitas Granger, uji variance decomposition dan impulse response function, uji Johansen Cointegration (model Natrex), serta uji regresi.

Hasil penelitian memberikan kesimpulan bahwa kebijakan nilai tukar yang diarahkan untuk menjaga keseimbangan internal dan eksternal sulit mencapai hasil maksimal, dalam arti mengandung trade off bagi otoritas moneter. Trade off dapat dikurangi melalui penurunan sensitivitas nilai tukar terhadap inflasi (pengurangan import content dalam struktur industri nasional) dan penurunan sensitivitas terhadap ekspor non migas (pembenahan iklim usaha dan peningkatan efisiensikapasitas produksi ekspor). Selanjutnya, hasil penelitian menunjukkan bahwa otoritas moneter seharusnya memprioritaskan tugas pada pemeliharaan stabilitas harga dibanding pada peningkatan ekspor, yang pada gilirannya mempertegas pandangan bahwwa sistem nilai tukar mengambang terkendali (managed floating) merupakan alternatif sistem nilai tukar yang akomodatif positif bagi rezim fixed dan flexible untuk memelihara ultimate target stabilitas harga (inflasi).

Perhitungan berdasarkan NATREX (Natural Real Exchange Rate) memberikan wawasan bahwa dalam jangka panjang beberapa variabel fundamental secara bersama-sama signifikan mempengaruhi nilai tukar riil di Indonesia. Dalam periode tertentu, NATREX sebagai pencerminan faktor fundamental mampu menjelaskan pergerakan nilai tukar riil, namun pada periode mengambang bebas (free floating) terlihat adanya perbedaan arah antara NATREX dengan nilai tukar riil (REER). Ini secara tidak langsung menyiratkan bahwa dalam kurun waktu tersebut gerakan nilai tukar ril juga dipengaruhi faktor di luar fundamental. Pada prinsipnya, target riil semakin sulit dicapai dalam era free floating, sehingga selama band nilai tukar tidak digunakan, maka intervensi otoritas moneter secara berkala ke pasar masih diperlukan, dengan syarat mempertimbangkan ketepatan timing, sifat, dan batas acuan intervensi yang didukung keberadaan Market Intelligence Unit. Selain itu, untuk meredam gejolak nilai tukar dan inflasi, tidak hanya bergantung pada kebijakan moneter dan nilai tukar semata, tetapi juga harus secara konsisten melaksanakan kebijakan susulan seperti kebijakan fiskal, restrukturisasi sektor keuangan dan reformasi struktur ekonomi (economic structural reform).

*) Doddy B. Waluyo : Peneliti Ekonomi , Bagian Studi Ekonomi dan Lembaga Internasional, UREM, BI, Email: doddy_w@bi.go.id

Benny Siswanto : Peneliti Ekonomi Yunior, Bagian Studi Ekonomi dan Lembaga Internasional, UREM, BI, Email: benny@bi.go.id

Penulis mengucapkan terima kasih untuk diskusi dan komentar dari Sjamsul Arifin, Kepala Bagian Studi Ekonomi dan Lembaga Internasional, UREM-BI, dan bantuan dalam proses penelitian kepada Harmanta, Asisten Peneliti Ekonomi, Bagian Studi Ekonomi dan Lembaga Internasional, UREM-BI. 


\section{Pendahuluan}

$\mathbf{U}$ ltimate target Bank Indonesia adalah kestabilan harga dan kemantapan neraca pembayaran. Untuk mencapai tujuan tersebut, selama ini kebijakan nilai tukar rupiah selalu diarahkan untuk menjaga keseimbangan internal dan eksternal tersebut, atau dengan kata lain, nilai tukar digunakan sekaligus sebagai alat daya saing (mendorong ekspor) dan sebagai alat moneter (kestabilan harga). Dalam kebijakan nilai tukar saat ini, dapat diperkirakan relatif cukup sulit bagi Bank Indonesia untuk mengarahkan nilai tukar ke level yang diinginkan seandainya kurs di pasar justru menghendaki arah yang berlawanan. Memang masih sulit untuk dipastikan apakah Bank Indonesia selamanya akan terus mengambangkan nilai tukar rupiah secara bebas atau tetap melakukan intervensi pasar secara berkala untuk menjaga keseimbangan internal dan eksternal tersebut. Seandainya pilihan kedua yang diambil berarti dapat diperkirakan bahwa jika nilai tukar berada di luar tingkat yang wajar (equilibrium level), Bank Indonesia akan kembali masuk ke pasar melalui intervensi spot dan forward secara berkala, selektif, dan timing yang tepat.

Memang diakui bahwa cukup sulit mendefinisikan nilai tukar yang equilibrium, mengingat banyak faktor fundamental dan tehnikal yang mempengaruhi equlibrium level tersebut. ${ }^{1}$ Namun secara umum equilibrium exchange rate dapat didefinisikan sebagai nilai tukar yang mencerminkan keseimbangan di pasar barang dan jasa serta di pasar uang, atau dengan kata lain nilai tukar yang realistis yang tidak anti bias ekspor dan sekaligus meningkatkan efektivitas pengendalian moneter. Dalam rangka menjaga keseimbangan di pasar barang dan jasa, maka nilai tukar tentunya harus dipertahankan pada level yang dapat mendukung competitiveness perekonomian dan ini berarti nilai tukar harus terus didepresiasi. Sementara dalam rangka keseimbangan di pasar uang, maka penetapan nilai tukar diarahkan untuk menjaga kestabilan besaran-besaran moneter, yang berarti nilai tukar harus terus diapresiasi.

Mengamati perkembangan kinerja perdagangan Indonesia selama ini, tidak dapat disangkal bahwa nilai tukar memang masih digunakan sebagai "tool" oleh otoritas moneter dalam mendorong ekspor. Depresiasi nilai tukar rupiah sampai dengan pertengahan tahun 1997 yang rata-rata berkisar antara 5-6\% pertahun memang ditujukan untuk keperluan daya saing produk ekspor Indonesia. Salah satu bukti dari hipotesa tersebut yaitu dengan mengamati perkembangan ke dua variabel tersebut pada tahun 1996 yang lalu. Pesatnya arus modal masuk luar negeri ke Indonesia di tahun itu memberi tekanan pada menguatnya rupiah, yang pada gilirannya dituding sebagai salah satu faktor penyebab melemahnya kinerja ekspor nonmigas Indonesia di tahun tersebut. Di sisi lain, pengaruh dari nilai tukar juga berdampak negatif terhadap kestabilan harga di dalam negeri (inflasi), mengingat ketergantungan yang cukup tinggi sektor industri di Indonesia pada impor barang modal dan bahan baku sebagai input produksi. Dengan demikian setiap depresiasi nilai tukar, yang ditujukan untuk mencapai keseimbangan eksternal, pada gilirannya justru akan menggangu keseimbangan internal melalui kenaikan imported inflation.

Bertolak dari kondisi tersebut di atas, permasalahannya disini adalah bagaimana menentukan nilai tukar yang dapat dianggap wajar mencerminkan kedua keseimbangan

1 Rosenberg, Michael R. “A Guide to Fundamental and Technical Models of Exchange Rate Determination”, Irwin Publication, 1996 
tersebut. Pertanyaan tersebut mungkin dapat dijawab dengan bertolak dari ultimate targets dari otoritas moneter itu sendiri. Apakah Bank Indonesia masih memberikan prioritas kepada pencapaian kestabilan transaksi berjalan dan kestabilan harga secara bersama-sama atau hanya pada kestabilan harga seperț halnya bank sentral di negara-negara maju ? Jika pilihan pertama yang masih diambil, pertanyaan di atas masih cukup relevan terlebih melihat kondisi sektor riil saat ini yang relatif belum mampu memberikan iklim yang kondusif bagi peningkatan ekspor. Sebaliknya jika Bank Indonesia beralih ke single target (kestabilan harga) maka tidak pada tempatnya Bank Indonesia memfokuskan upaya-upaya mendorong ekspor melalui nilai tukar.

Berdasarkan latar belakang tersebut, maka penelitian ini bertujuan untuk mengetahui seberapa besar efektifitas dari penetapan nilai tukar rupiah selama ini dalam mencapai keseimbangan tersebut. Hal itu dapat didekati dengan melihat seberapa besar sensitivitas nilai tukar terhadap ekspor nonmigas, dan seberapa besar sensitivitas nilai tukar dalam pembentukan harga. Dari pengenalan atas karakteristik tersebut, selanjutnya dapat ditentukan arah kebijakan nilai tukar rupiah di masa mendatang. Selain itu, sehubungan dengan adanya gejolak nilai tukar Rupiah pada awal semester II 1997 yang dikhawatirkan dapat mengganggu cadangan devisa Indonesia, maka pada tanggal 14 Agustus 1997 pemerintah memutuskan untuk melepas nilai tukar Rupiah ke mekanisme pasar (free floating). Penghapusan band intervensi berarti memberi kebebasan penuh pada pasar untuk menetapkan nilai tukar, dan ini berarti nilai tukar dapat saja over-under shooting sesuai dengan keinginan pasar. Atas dasar itu, maka penelitian ini juga bertujuan untuk menelaah volatilitas nilai tukar dalam era free floating.

\section{Metodologi}

Penelitian dilakukan untuk mengetahui hubungan antara nilai tukar dengan keseimbangan internal (yang diwakili oleh inflasi) dan keseimbangan eksternal (yang diwakili oleh ekspor nonmigas). Sensitivitas nilai tukar terhadap inflasi melalui indikator CPI dan WPI, masing-masing berbeda. Sementara itu, untuk ekspor nonmigas akan dilihat sensitivitas nilai tukar terhadap total ekspor dan masing-masing sektor yaitu manufaktur, pertanian, dan pertambangan, mengingat price sensitivity di masing-masing sektor berbeda.

Periode observasi penelitian meliputi kurun waktu triwulan I 1983 - triwulan III 1997 dan triwulan III 1997 - triwulan I 1998, dengan dukungan data kuartalan yang dihimpun dari berbagai sumber. Untuk periode triwulan I 1983 - triwuan III 1997, metode yang digunakan adalah uji hubungan Granger Causality (untuk mengetahui kausalitas antara kedua variabel), uji Variance Decomposition dan Impulse Response Function (untuk mengetahui simpangan residual dari kedua variabel tersebut), serta uji regresi (untuk mengetahui sensitivity level). Sementara itu, dalam periode observasi triwulan III 1997 - triwulan I 1998, penetapan nilai tukar beralih ke sistem mengambang bebas (free floating), sehingga metode penelitian dilengkapi dengan alternatif model dinamis NATREX (Natural Real Exchange Rate) beserta uji Johansen Cointegration dan uji regresi.

Data nilai tukar yang digunakan berdasarkan kurs konversi dan kurs antar bank, serta dinyatakan dalam nilai tukar riil (bukan nominal). Pendekatan secara riil ini adalah yang paling tepat untuk mengetahui kekuatan nilai mata uang yang sebenarnya (overvalued atau undervalued) dibandingkan dengan menggunakan pendekatan nominal. Sebagai 
tahun dasar dan basket digunakan beberapa alternatif yaitu tahun dasar Juni 1988 $=100$ dan 1992=100, sementara untuk basket digunakan nilai perdagangan ( 5 dan 8 negara) dan valuta perdagangan (1 dan 3 valuta). Demikian pula sebagai proksi harga digunakan CPI dan WPI (Wholesale Price Index).

\section{Perkembangan Nilai Tukar}

\section{Kebijakan Nilai Tukar}

Kebijakan nilai tukar pada dasarnya mempunyai fungsi ganda, pertama yaitu untuk mempertahankan keseimbangan neraca pembayaran yang akhirnya bermuara kepada tingkat kecukupan cadangan devisa yang dikelola oleh Bank Indonesia. Oleh karena itu dalam menetapkan arah kebijakan nilai tukar tersebut diutamakan untuk mendorong dan menjaga competitiveness ekspor nonmigas dalam upaya untuk memperkecil defisit current account. Fungsi kedua, adalah untuk menjaga kestabilan pasar domestik. Fungsi ini untuk menjaga agar nilai tukar tidak dijadikan sebagai suatu "tool" yang akan menambah atau mengurangi likuiditas masyarakat, dalam arti bahwa apabila masyarakat menilai USD terlalu murah (Rupiah overvalued) maka mereka akan memborong USD, sebaliknya apabila nilai USD terlalu mahal (Rupiah undervalued) maka mereka akan menjual USD kepada Bank Indonesia. Ketidakstabilan pasar domestik yang demikian dapat menimbulkan kegiatan spekulatif seperti perkembangan akhir-akhir ini, yang pada gilirannya dapat mengganggu kestabilan perekonomian makro.

Penetapan nilai tukar nominal pada umumnya menggunakan pendekatan Purchasing Power Parity $: \mathrm{Pdn}=\mathrm{e}^{*} \mathrm{Pln}$ atau $\mathrm{e}=\mathrm{Pdn} / \mathrm{Pln}$. Teori ini mengatakan bahwa perubahan nilai tukar mata uang sama dengan perbedaan tingkat inflasi di kedua negara. Dalam teori ini nilai tukar sebagai adjustment factor antara perbedaan inflasi di dalam dan luar negeri, mengingat penyamaan perbedaan inflasi tersebut tidak dapat dilakukan setiap saat dan merupakan fenomena jangka panjang. Nilai tukar (e) yang menurun mencerminkan depresiasi, dan sebaliknya mencerminkan apresiasi. Pergerakan dari e tersebut selanjutnya dapat diketahui apakah realistis atau tidak dengan melihat nilai riilnya apakah dalam posisi overvalued atau undervalued dari nilai tukar riil tersebut. Dengan demikian, penetapan nilai tukar nominal yang tepat baik secara langsung melalui kebijakan nilai tukar maupun secara tidak langsung melalui kebijakan moneter yang diarahkan pada target nilai tukar, sangat penting untuk menghindarkan misalignment nilai tukar riil tersebut ${ }^{2}$.

Pada prinsipnya ada tiga sistem yang digunakan dalam kebijakan nilai tukar rupiah sejak tahun 1971 hingga sekarang. Antara tahun 1971 hingga 1978 dianut sistem nilai tukar tetap (fixed exchange rate) dimana nilai Rupiah secara langsung dikaitkan dengan nilai USD. Sejak 15 November 1978 sistem nilai tukar diubah menjadi mengambang terkendali (managed floating exchange rate) dimana nilai Rupiah tidak lagi semata-mata dikaitkan dengan

2 Misalignment nilai tukar riil dari posisi equilibrium umumnya disebabkan oleh pelaksanaan kebijakan makroekonomi yang tidak konsisten dengan sistim nilai tukar yang berlaku, serta external shocks. Misalignment dari nilai tukar riil dapat berdampak pada ongkos produksi di dalam negeri dan tingkat konsumsi tradable dan nontradable goods. Lebih jelas lihat Edwards, Sebastian "Exchange Rate Misalignment in Developing Countries", IMF 1992 
USD, namun terhadap sekeranjang valuta partner dagang utama. Maksud dari sistem nilai tukar tersebut adalah bahwa meskipun diarahkan ke sistem nilai tukar mengambang namun tetap menitik beratkan unsur pengendalian. Dengan kata lain sistem nilai tukar yang dijalankan adalah stable but adjustable exchange rate, dalam arti Bank Indonesia selalu berupaya untuk menciptakan kurs Rupiah yang realistis yang mampu menunjang daya saing produk dalam negeri dan juga meningkatkan kepercayaan masyarakat terhadap Rupiah yang pada akhirnya dapat menciptakan kestabilan moneter.

Perubahan mendasar dalam kebijakan mengambang terkendali tersebut terjadi pada tanggal 14 Agustus 1997, dimana jika sebelumnya Bank Indonesia menggunakan band sebagai guidance atas pergerakan nilai tukar maka sejak saat itu tidak ada lagi band sebagai acuan nilai tukar. Namun demikian cukup sulit menjawab apakah memang nilai tukar rupiah sepenuhnya di lepas ke pasar (free floating), atau masih akan dilakukan intervensi oleh Bank Indonesia. Dengan mengamati segala dampak dari sistim free floating serta dikaitkan dengan kondisi/struktur perekonomian Indonesia selama ini, nampaknya penerapan purely free floating sulit untuk dilakukan. Kemungkinannya adalah Bank Indonesia akan tetap mempertahankan managed floating dengan melakukan intervensi secara berkala, selektif, dan pada timing yang tepat.

\section{Perkembangan Nilai Tukar Nominal}

Perkembangan nilai tukar nominal rupiah selama periode managed floating dapat dilihat dalam grafik 1. Periode managed floating diperkenalkan sejak tahun 1978 dan berlaku hingga pertengahan tahun 1997. Dalam implementasinya selama ini, sistim managed floating tersebut mempunyai karakteristik yang berbeda-beda sesuai dengan kondisi perekonomian saat itu. Karakteristik tersebut sangat menonjol dalam konteks seberapa besar Bank Indonesia melakukan penekanan pada unsur management atau unsur floating nya.

Periode 1978 - 1986 dapat dianggap sebagai periode Managed Floating I dimana unsur management lebih besar dari floating. Hal ini ditunjukkan oleh pergerakan nilai tukar nominal yang relatif tetap dan perubahan relatif baru terjadi pada tahun-tahun tertentu,

Grafik 1.

Perkembangan Nilai Tukar Rp/USD

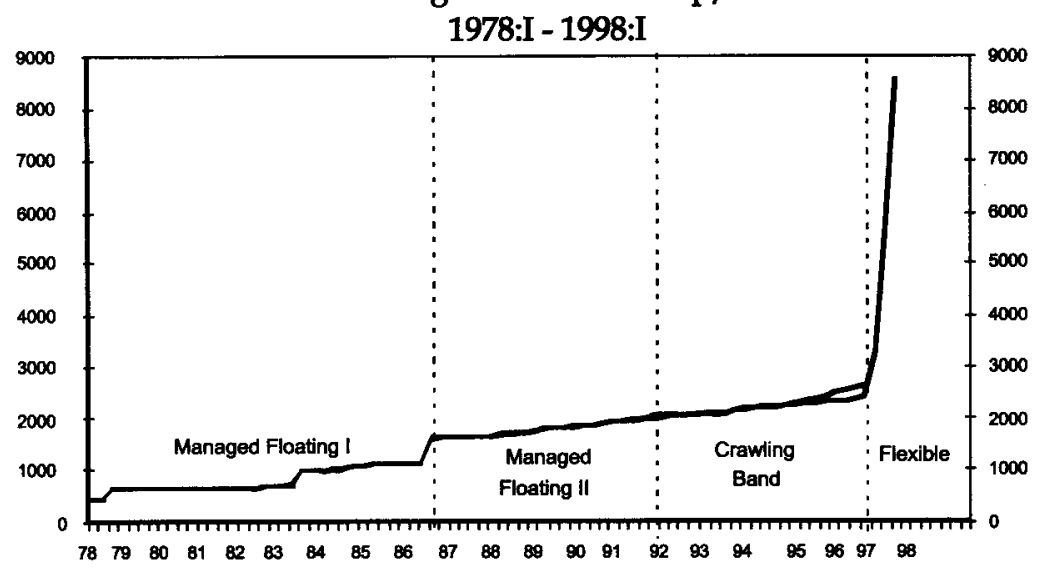


yaitu pada saat Bank Indonesia melakukan devaluasi rupiah. Cukup kuatnyä unsur managed dalam periode tersebut tidak terlepas dari kondisi perekonomian yang relatif belum berkembang pada saat itu sehingga memudahkan Bank Indonesia melakukan penyesuaian nilai tukar sesuai target yang diinginkan.

Namun dalam perkembangan selanjutnya dengan semakin terbukanya perekonomian yang ditandai dengan berbagai kebijakan deregulasi di sektor ekonomi, semakin aktifnya sektor swasta, dan semakin "sempurna"nya mekanisme pasar, kebijakan nilai tukar memasuki periode Managed Floating II (1987-1992) dimana unsur floating kini lebih dominan dibandingkan unsur management. Dalam periode ini, dimana kekuatan pasar semakin besar, unsur floating semakin dirasakan perlu mengingat management yang terlalu dominan dapat berakibat misalignment pada nilai tukar riil. Dalam grafik 1 terlihat bahwa perubahan nilai tukar terjadi setiap saat, dan ini sebagai cerminan dari upaya Bank Indonesia untuk lebih menyesuaikan nilai tukar rupiah dengan kondisi pasar / perekonomian saat itu. Namun demikian unsur management tetap dilakukan oleh Bank Indonesia, khususnya dalam rangka competitivenes produk ekspor, melalui pergerakan mata uang dalam kisaran yang sempit (band kurs konversi sebesar $2 \%$ ).

Fleksibilitas nilai tukar dalam periode managed floating II ini selanjutnya semakin diperkuat dengan pelaksanaan sistem crawling band, yang diperkenalkan sejak tahun 1992 hingga 1997 (Agustus) dimana dalam periode ini, unsur floating semakin "diperkenankan" dalam kisaran yang semakin lebar. Dalam grafik I terlihat bahwa Bank Indonesia secara kontinyu terus mendepresiasi rupiah sebesar inflation differential, sementara dalam waktu yang bersamaan meningkatkan fleksibilitas jangka pendek dari rupiah melalui pelebaran intervention band intervensi secara bertahap (total sebanyak 8 kali). Perkembangan fleksibilitas rupiah ini selanjutnya semakin diperkuat dengan penghapusan band intervensi (sejak Agustus 1997) dimana rupiah kini relatif lebih floating dibandingkan periode-periode sebelumnya. Namun demikian unsur management kemungkinan tetap akan dilaksanakan oleh Bank Indonesia, meskipun dalam porsi yang tidak terlalu besar, khususnya dalam rangka mencapai level yang dianggap wajar.

\section{Perkembangan Nilai Tukar Riil Basket}

Untuk mengevaluasi penetapan nilai tukar nominal di atas, maka dilakukan perhitungan RER. Nilai tukar riil mencerminkan harga relatif dari dua barang. Secara spesifik nilai tukar riil adalah $\mathrm{RER}=$ Price of tradable goods (dlm domestic currency) / Price of nontradable goods, atau $\mathrm{RER}=\mathrm{E}$ * $\mathrm{Pt} / \mathrm{Pn}$ dimana $\mathrm{E}$ adalah nominal exchange rate, $\mathrm{Pt}$ adalah harga tradable goods, dan Pn adalah harga non tradable goods. Mengingat price ratio lebih bersifat exogeneous, maka penetapan $E$ yang tepat akan menentukan apakah RER berada dalam level keseimbangan (nilai 100), atau di luar keseimbangan dimana rupiah dinilai terlalu mahal (nilai < 100) atau terlalu murah (nilai $>100$ ).

Perkembangan nilai tukar riil efektif basket (basket 8 negara partner dagang dan tahun dasar Juni 1988=100) dapat dilihat dalam grafik 2.

Selama periode managed floating I (1983 - 1986) REER menunjukkan posisi overvalued yang semakin kecil (indeks menuju 100 kebawah). Relatif mahalnya rupiah, yang pada gilirannya dikhawatirkan akan berpengaruh pada daya saing, memaksa Bank Indonesia secara kontinyu mendepresiasi nilai tukar nominal (NEER) relatif di atas pertumbuhan 


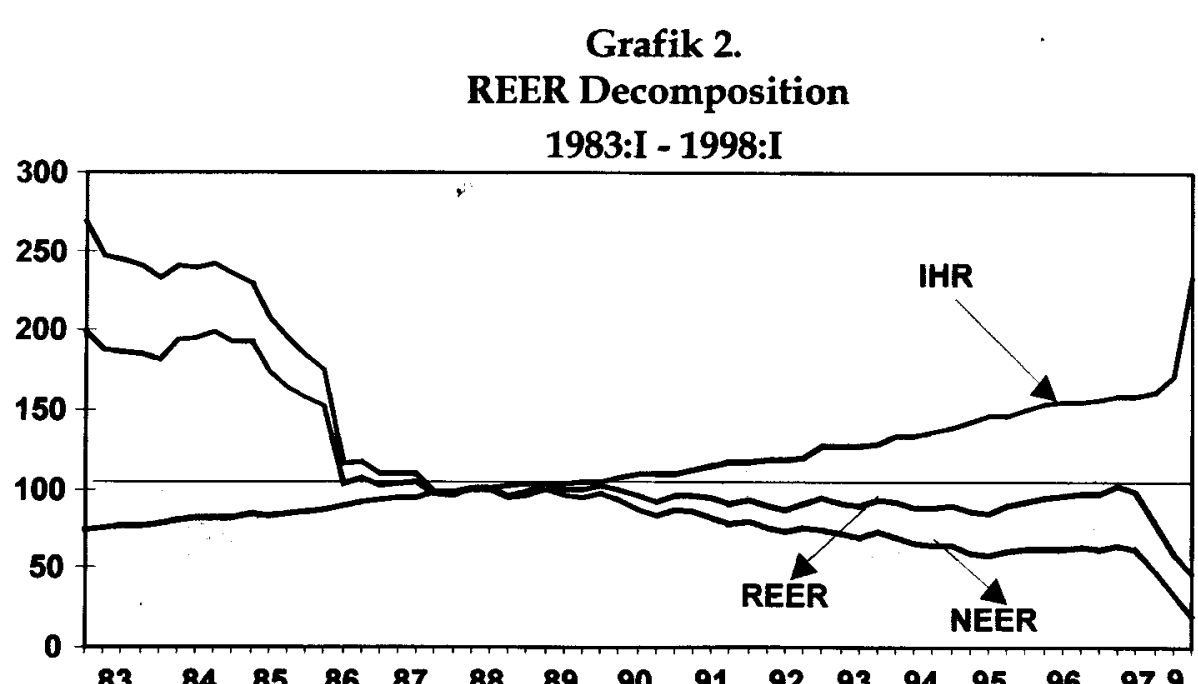

harga relatif (IHR) sehingga menyebabkan REER mengalami depresiasi yang cukup besar. Selanjutnya dalam periode managed floating II (1987-1992) REER telah menunjukkan posisi undervalued dengan pergerakan ke bawah yang relatif stabil. Namun pergerakan REER kembali cenderung menguat (ke atas) sejak tahun 1992 seiring dengan pesatnya capital inflows dan kebijakan crawling bands. Depresiasi NEER cenderung mengecil dan relatif lebih kecil dari perubahan IHR, bahkan pada beberapa tahun (1993 dan 1995-1997.II) menunjukkan apresiasi. Menguatnya NEER tersebut menyebabkan REER kembali overvalued di triwulan I 1997, sebelum kembali melemah setelah band nilai tukar dihapus.

Apabila diamati perkembangan REER selama periode active exchange rate management $^{3}$ (sejak tahun 1992) tersebut, nampak bahwa kecenderungan menguatnya REER tersebut selain disebabkan apresiasi NEER, juga oleh depresiasi NEER yang lebih kecil dari perubahan IHR. Beberapa faktor yang berpengaruh diantaranya adalah tingginya permintaan terhadap rupiah selama periode capital inflows serta melemahnya USD terhadap Yen Jepang di tahun 1994-1995. Cukup dominannya bobot USD dalam penetapan nilai tukar selama ini membawa konsekuensi setiap melemahnya USD terhadap mata uang utama dunia akan menguatkan nilai rupiah (NEER), dan sebaliknya. Di samping itu penurunan pertumbuhan IHR seiring dengan membaiknya CPI domestik pada gilirannya turut berpengaruh pada pergerakan REER di periode tersebut

Evaluasi terhadap perkembangan REER selanjutnya dapat dilihat dari berbagai alternatif perhitungan yang digunakan, yaitu dengan menggunakan CPI dan WPI sebagai proksi IHR; tahun dasar Juni 1988=100 dan 1992=100; dan basket yang berbeda yaitu berdasarkan negara partner dagang ( 5 negara dan 8 negara) dan valuta perdagangan (1 valuta dan 3 valuta). Perkembangan REER dengan tahun dasar Juni 1988=100 dapat dilihat dalam grafik 3 (REER dengan menggunakan CPI) dan grafik 4 (REER dengan menggunakan WPI), sementara dengan tahun dasar 1992=100 dapat dilihat dalam grafik 5 (REER dengan menggunakan CPI) dan grafik 6 (REER dengan menggunakan WPI). 
Grafik 3.

Perkembangan REER Berdasarkan Berbagai Alternatif Bobot (Juni 1988 = 100)

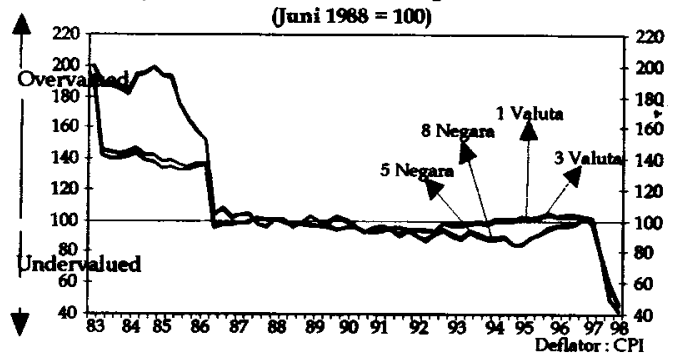

Grafik 5.

Perkembangan REER Berdasarkan Berbagai Alternatif Bobot (Tahun 1992 = 100)

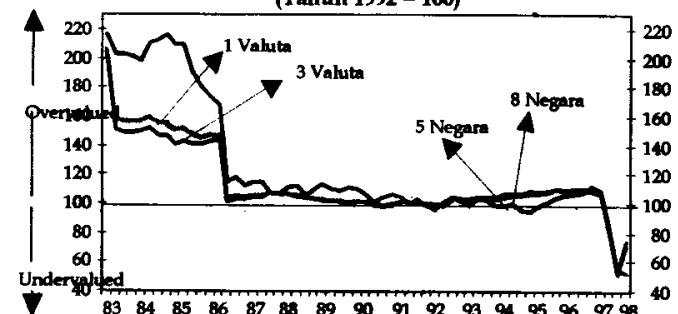

Deflator : CPI
Grafik 4.

Perkembangan REER Berdasarkan Berbagai Altematif Bobot Ouni 1988 = 100)

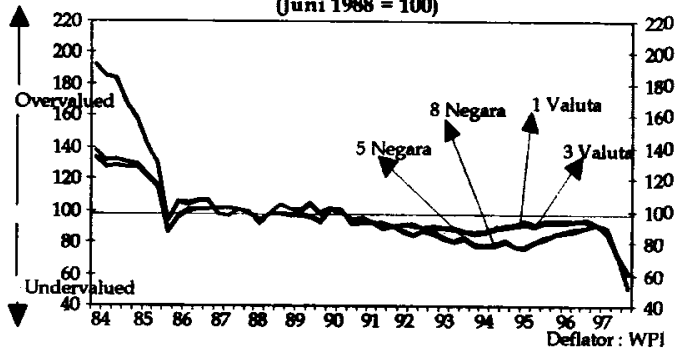

Grafik 6.

Perkembangan REER Berdasarkan Berbagai Alternatif Bobot

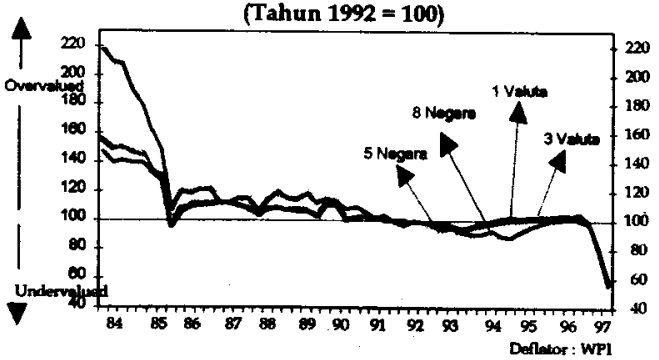

Dengan menggunakan tahun dasar Juni 1988=100 dan CPI sebagai proksi IHR (grafik 3), REER dengan basket negara perdagangan ( 5 negara dan 8 negara) relatif dalam posisi undervalued sejak tahun 1987 meskipun di awal tahun 1997 cenderung kembali menguat (overvalued). Sementara itu dengan basket valuta perdagangan (1 valuta dan 3 valuta), REER justru telah kembali overvalued sejak tahun 1994. Selanjutnya jika digunakan WPI sebagai proksi IHR (grafik4),REER dengan alternatif basket negara perdagangan dan valuta perdagangan cenderung dalam posisi undervalued sejak akhir tahun 1990

Dengan menggunakan tahun dasar 1992=100 dan CPI sebagai proksi IHR (grafik 5), REER dengan basket negara perdagangan ( 5 negara dan 8 negara) relatif dalam posisi overvalued (kecuali tahun 1992 dan 1994) sementara dengan basket valuta perdagangan (1 valuta dan 3 valuta), REER juga berada dalam posisi overvalued. Sementara itu jika digunakan WPI sebagai proksi IHR (grafik 6), REER dengan alternatif basket negara perdagangan dan valuta perdagangan relatif dalam posisi overvalued (kecuali tahun 1992-1996 dengan basket negara perdagangan.

Dari hasil pengamatan grafik 3-6 dapat ditarik beberapa kesimpulan yaitu :

1. REER dengan tahun dasar $1992=100$ mempunyai kecenderungan berada di atas indeks 100 yang menunjukkan posisi overvalued atau tidak kompetitif. Sebaliknya dengan tahun dasar Juni 1988=100, posisi REER cenderung undervalued atau lebih kompetitif.

2. Pergerakan REER dengan basket valuta perdagangan relatif lebih stabil dibandingkan dengan pergerakan REER dengan basket negara pedagangan. Perbedaaan tersebut dapat dijelaskan karena meskipun perdagangan internasional Indonesia dilakukan dengan 
banyak negara partner dagang, namun valuta yang digunakan sebagian besar dalam USD (atau Yen dan Sin dollar). Dengan demikain REER dengan basket valuta relatif lebih merefleksikan kekuatan dari nilai tukar.

3. REER yang dihitung dengan CPI sebaǵai proksi IHR cenderung lebih tinggi dibandingkan dengan alternatif WPI.

Dari kesimpulan sementara di atas, ada beberapa hal yang dapat menjadi pertanyaan yaitu:

1. Apakah REER yang cenderung menguat khususnya sejak diterapkannya crawling band, berkorelasi dengan melemahnya kinerja ekspor non migas Indonesia (growth ekspor nonmigas sekitar 31\% tahun 1992 dan turun menjadi sekitar $8 \%$ tahun 1996) ? Demikian pula halnya dengan kondisi nilai tukar saat ini, apakah melemahnya REER sebagai akibat gejolak nilai tukar akan berpengaruh positif pada kinerja ekspor nonmigas di tahun ini ?

2. Di tengah-tengah pesatnya capital inflows (periode pre-krisis rupiah), apakah pelaksanaan kebijakan nilai tukar yang cenderung "more" depreciative atau "less" appreciative sudah tepat dalam mempengaruhi tingkat inflasi atau dengan kata lain tidak berdampak inflatoir ? Apakah dengan penghapusan band nilai tukar saat ini, akan berpengaruh negatif terhadap tingkat inflasi?

Seandainya jawaban atas pertanyaan 1 menunjukkan hubungan yang signifikan, secara tidak langsung dapat dikatakan bahwa kebijakan nilai tukar rupiah yang cenderung depresiatif selama ini memang sudah tepat. Bahkan "to some extent" depresiasi rupiah harus dipercepat untuk memperbaiki kinerja ekspor nonmigas tersebut. Sebaliknya, jika jawaban atas pertanyaan di atas tidak conclusive maka sudah saatnya untuk lebih mengambangkan rupiah sesuai dengan kekuatan pasar.

\section{Hubungan Nilai Tukar Dan Ekspor Non Migas}

Berdasarkan teori, nilai tukar mata uang suatu negara berperan dalam perkembangan ekspor maupun impor negara tersebut ${ }^{4}$. Apabila mata uang mengalami depresiasi maka ekspor akan meningkat karena harga barang ekspor lebih murah dinilai dalam mata uang negara lain (mitra dagang) dan impor menurun karena harga barang impor naik dalam mata uang sendiri. Namun kenyataannya, hal tersebut tidak selalu terjadi karena masih tergantung pada beberapa faktor antara lain jenis barang ekspor/impor dan kapasitas industri negara yang bersangkutan. Ekspor yang didominasi oleh barang yang kurang elastis terhadap perubahan harga seperti makanan pokok maka penurunan nilai mata uang tidak akan banyak membantu peningkatan ekspor. Barang modal juga merupakan jenis barang impor yang kurang respons terhadap melemahnya suatu mata uang. Perlu diingat pula, bahwa jenis pinjaman yang diterima suatu negara kerap berupa keharusan untuk mengimpor barang dari negara donor (in kind loan) yang berarti tidak lagi memperhatikan nilai tukar yang berlaku. Di samping itu, dalam kondisi perekonomian dimana industri telah mencapai full capacity maka depresiasi juga tidak akan banyak pengaruhnya terhadap ekspor. 
Grafik 7.

Pertumbuhan Tahunan REER dan Total Ekspor Non Migas

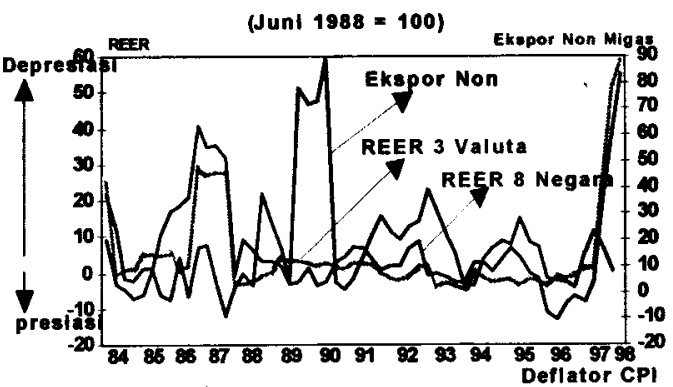

Grafik 8.

Pertumbuhan Tahunan REER dan Total Ekspor Non Migas

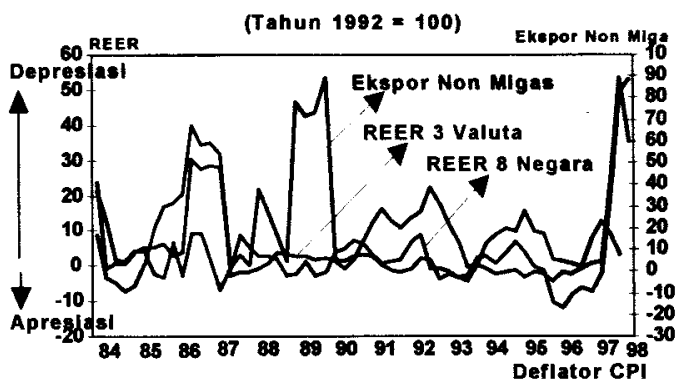

Secara umum, perkembangan total ekspor nonmigas di Indonesia dalam jangka panjang ternyata selalu sejalan dengan perkembangan nilai tukar riil basket (REER). Dalam grafik 7 dapat dilihat bahwa kecenderungan melemahnya (depresiasi) REER (8 negara dan 3 valuta), dalam periode jangka panjang 1983-1995 relatif diikuti dengan meningkatnya nilai total ekspor nonmigas. Demikian pula sebaliknya, pada saat REER tersebut menguat (apresiasi) nilai ekspor nonmigas cenderung menurun atau hanya sedikit mengalami peningkatan. Hubungan antara ekspor nonmigas dengan nilai tukar riil basket tersebut juga menujukkan kecenderungan hasil yang sama seandainya digunakan tahun dasar 1992=100 (grafik 8).

Dari analisis grafik, terbukti bahwa kebijakan depresiatif nilai tukar selama ini relatif mempunyai hubungan searah dengan perkembangan total ekspor nonmigas Indonesia. Sementara pada periode-periode tertentu (1996-awal 1997), dimana nilai tukar lebih dipengaruhi oleh perkembangan valuta asing (sejalan dengan pesatnya dana luar negeri yang masuk dan relatif tidak terkait dengan transaksi ekspor), berpengaruh pada melemahnya kinerja ekspor nonmigas. Namun demikian jika diamati menurut jenis barang ekspor maka hanya jenis barang manufaktur yang mempunyai elastisitas yang tinggi. Ekspor barang tambang dan pertanian relatif kurang sensitif dengan nilai tukar mengingat posisi Indonesia adalah sebagai price taker didalam perdagangan internasional.

Untuk mengetahui seberapa besar keterkaitan antara nilai tukar riil basket dengan ekspor nonmigas telah dilakukan uji hubungan dengan menggunakan data kuartalan dengan pembagian periode observasi yaitu :

- 1983.I - 1997.II sebagai periode jangka panjang

- 1989.I - 1997.II sebagai periode capital inflows.

Hasil temuan sementara yang diperoleh adalah sebagai berikut:

1. Dari hasil Uji Hubungan Granger Causality (tabel 1 dan 2) menunjukkan bahwa (i) selama periode 1983.I - 1997.II, hanya nilai tukar (riil basket dan nominal) yang mempunyai kausalitas ke arah total ekspor nonmigas (volume), (ii) daya prediksi nilai tukar relatif hanya moderat, yang ditunjukkan oleh periode kemampuan nilai tukar menjelaskan perilaku total ekspor nonmigas (volume) rata-rata setelah lag 8 triwulan (observasi 1983.I1997.II dan observasi 1989.I-1997.II). Nilai tukar riil basket mampu pula menjelaskan perilaku total ekspor nonmigas setelah lag 3 triwulan (observasi 1989.I-1997.II) namun kemudian hubungan tersebut hilang dan baru muncul setelah lag 8 triwulan. 
2. Dari hasil Uji Variance Decomposition (tabel 3 dan 4) menunjukkan bahwa (i) inflasi, harga ekspor (deflator) dan nilai tukar mempunyai predictive power yang terkuat terhadap total ekspor nonmigas (di luar dirinya sendiri), tetapi kemampuan prediksi nilai tukar relatif moderat dalam menjelaskan error variance total ekspor nonmigas, dibandingkan inflasi dan harga ekspor, (ii) nilai tukár riil basket hanya mampu menjelaskan sekitar $5 \%$ dari error variance (maksimum $8 \%$ ) total ekspor nonmigas pada periode 2 triwulan di muka (observasi 1983.I-1997.II) atau sekitar 1\% (maksimum 2\%) pada periode 3 triwulan di muka (observasi 1989.I-1997.II), (iii) sekitar 50\%-80\% dari error variance total ekspor nonmigas (volume) diterangkan oleh dirinya sendiri, (iv) variasi ekspor non-migas dipengaruhi terutama oleh dirinya sendiri, deflator ekspor barang dan jasa, past performance inflasi, dan nilai tukar, dan (v) dalam jangka yang lebih panjang pengaruh nilai tukar semakin meningkat dalam menjelaskan variasi ekspor non-migas.

Grafik 9.

Perkembangan REER dan Ekspor Non Migas Menurut Jenis (Juni $1988=100)$

Ekspor Non Migas

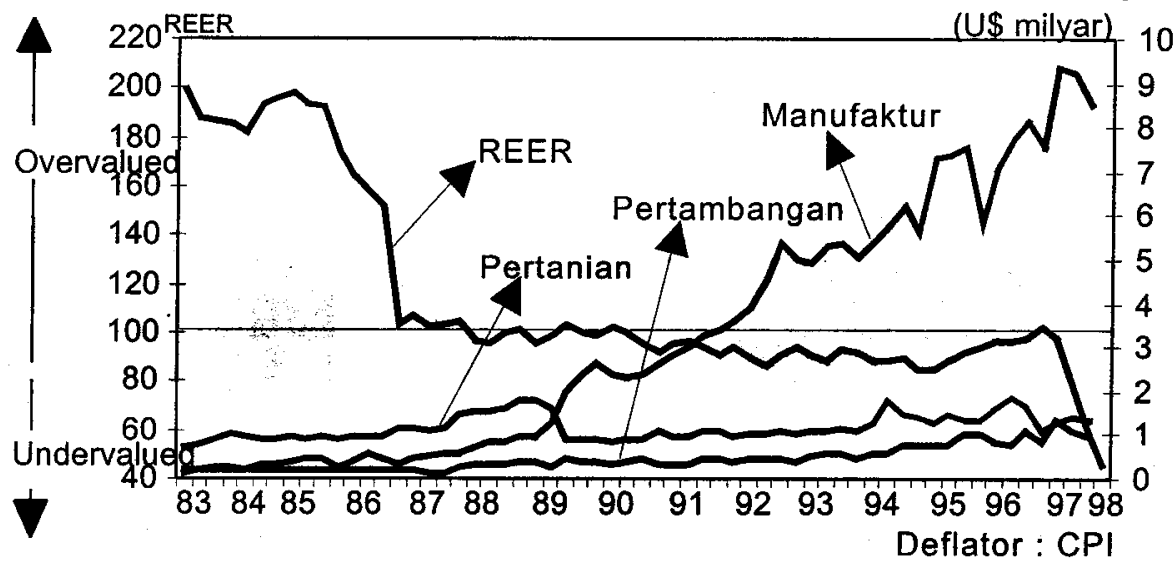

Grafik 10.

Error Variance Decomposition of Non Oil/Gas Exports 1983.I - 1997.II

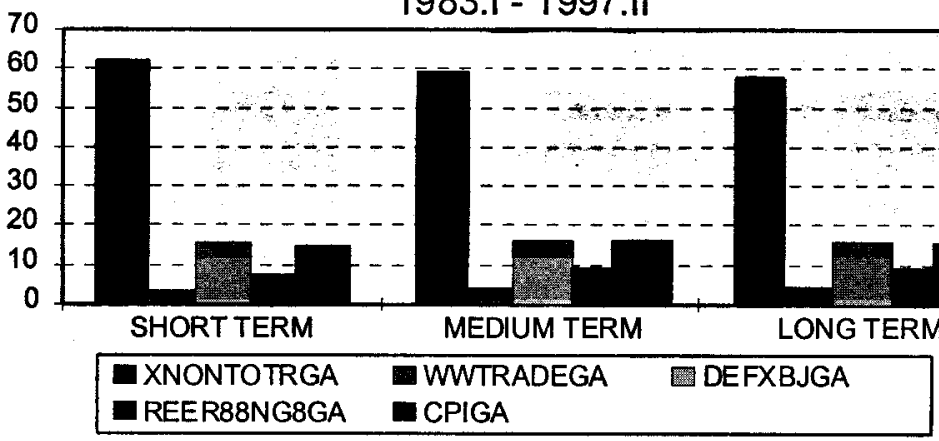


3. Dari hasil uji Impulse Response Function dari VAR (grafik 11) menunjukkan bahwa (i) shocks dari ekspor nonmigas (volume) yang berasal dari suatu perubahan innovation nilai tukar riil basket relatif kecil dan berlangsung singkat yaitu sekitar 6 periode di muka dan kemudian relatif hilang. Demikian pula perubahan dari world trade hanya memberi shocks yang relatif kecil pada ekspor nonmigas (volume) namun relatif berlangsung pada periode yang cukup panjang, dan (ii) shocks yang cukup besar dari ekspor nonmigas dirasakan dari perubahan inflasi dan harga ekspor (deflator).

4. Dari hasil Uji Regresi terhadap ekspor nonmigas (volume) dengan menggunakan variabel nilai tukar riil basket 8 negara dan 3 valuta perdagangan serta tahun dasar Juni 1988 dan 1992=100 (tabel 5) menunjukkan bahwa (i) elastisitas nilai tukar riil basket terhadap ekspor nonmigas (volume) dgn perhitungan basket valuta (sekitar 0,6-0,8) lebih

\section{Grafik 11}

Response to One S.D. Innovations \pm 2 S.E
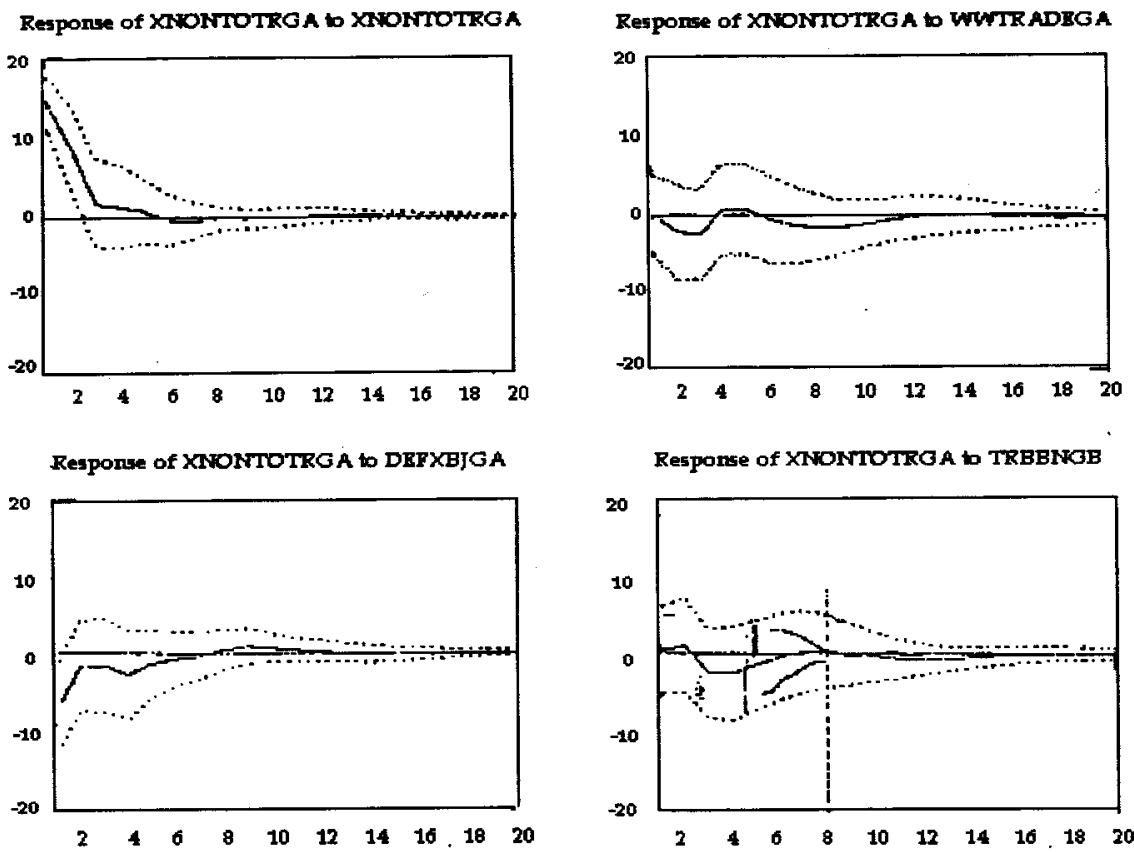

Resporise of XNONTOTRGA to CPIGA

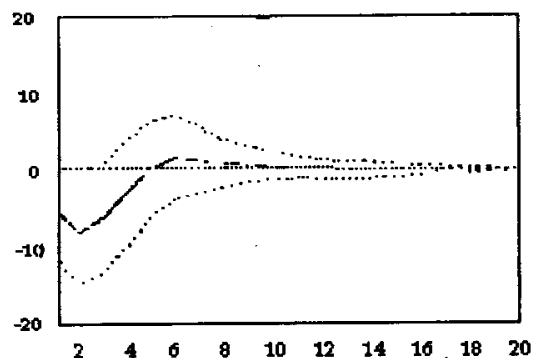


besar dibandingkan dengan perhitungan basket negara (0,4-0,5), untuk masing-masing tahun dasar, (ii) elastisitas tersebut relatif lebih besar pada periode 1989.I-1997.II (sekitar 0,5-0,8) dibandingkan periode 1983.I-1997.II (0,4-0,6), (iii) dampak perubahan nilai tukar terhadap ekspor nonmigas relatif lebih cepat dirasakan dalam periode 1989.I-1997.II (sekitar 2-6 triwulan dimuka) dibandingkan periode 1983.I-1997.II (11 triwulan dimuka), (iv) volume perdagangan dunia dan harga relatif (harga ekspor luar negeri terhadap harga jual dalam negeri) mempunyai elastisitas masing-masing sekitar 0,6 dan 0,5 terhadap ekspor nonmigas, dan (v) kemampuan menjelaskan persamaan ekspor nonmigas (volume) relatif cukup baik yaitu mencapai sekitar $80 \%$ dengan standard error of correction sekitar $0,15 \%$

5 Dari hasil beberapa pengujian di atas, selanjutnya dapat ditarik beberapa kesimpulan yaitu (i) dengan elastisitas yang cukup besar dan signifikan tersebut, maka kebijakan depresiatif rupiah yang dilaksanakan selama ini memang cukup beralasan dalam mempengaruhi kinerja ekspor nonmigas, hanya saja pengaruh dari perubahan nilai tukar tersebut terhadap ekspor nonmigas tidak segera dan memerlukan time lag tertentu, (ii) pengaruh nilai tukar dalam mendorong ekspor semakin besar dan semakin cepat dalam periode 8 tahun terakhir (1989.I-1997.II). Hal ini berkaitan dengan semakin berkembangnya ekspor manufaktur dimana lebih sensitif terhadap perubahan nilai tukar, relatif dibandingkan pertumbuhan ekspor pertambangan dan pertanian. Dapat diinformasikan besarnya elastisitas nilai tukar riil basket terhadap ekspor barang manufaktur sekitar 0,6 dengan lag 2 triwulan (1989.I-1997.II) dan 6 triwulan (1983.I1997.II). Sebagai perbandingan, studi yang dilakukan oleh J.McDermott (1996) ${ }^{1}$ menunjukkan besarnya koefisien tersebut sebesar 0,32 , yang berarti satu persen depresiasi REER akan menaikan ekspor manufaktur sebesar $0,32 \%$, dan (iii) lebih sensitifnya nilai tukar riil dengan perhitungan basket valuta dibandingkan basket negara dikarenakan oleh dominasi mata uang utama sebagai alat pembayaran perdagangan. Kondisi ini dapat menjadi indikasi bahwa perhitungan nilai tukar riil dengan basket valuta menjadi lebih tepat dibandingkan dengan basket negara.

Sementara itu perkembangan nilai tukar riil basket dengan impor nonmigas dapat diamati dalam grafik 12. Hubungan antara nilai tukar dengan impor nonmigas relatif tidak conclusive, sejalan dengan karakteristik industri dalam negeri dengan impor content yang cukup tinggi. Ini berarti untuk mempertahankan kesinambangunan kegiatan perekonomian, kebutuhan akan produk impor akan tetap tinggi terlepas pada levelnilai tukar yang terjadi. Salah satunya ditunjukkan oleh sekitar $10 \%$ dari nilai impor nonmigas Indonesia (atau sekitar $25 \%$ pada periode 1980 an) berupa impor barang-barang yang tidak sensitif dengan nilai tukar seperti impor dalam rangka program (seperti beras, gula, gandum) dan impor dalam rangka project aid pemerintah (terkait dengan bantuan CGI dan-non CGI): Dalam grafik terlihat adanya kecenderungan pada saat rupiah mengalami apresiasi impor nonmigas cenderung meningkat, namun pada saat rupiah depresiasi impor nonmigas relatif tidak melambat. Test regressi terhadap impor nonmigas (tabel 6) menunjukkan bahwa kinerja impor nonmigas sangat ditentukan oleh variabel-variabel lain di luar nilai tukar, yaitu oleh dirinya sendiri (lag 1 triwulan) dan kegiatan ekonomi domestik (GDP). 


\section{Grafik 12.}

\section{Pertumbuhan Tahunan REER dan Total Impor Non Migas}

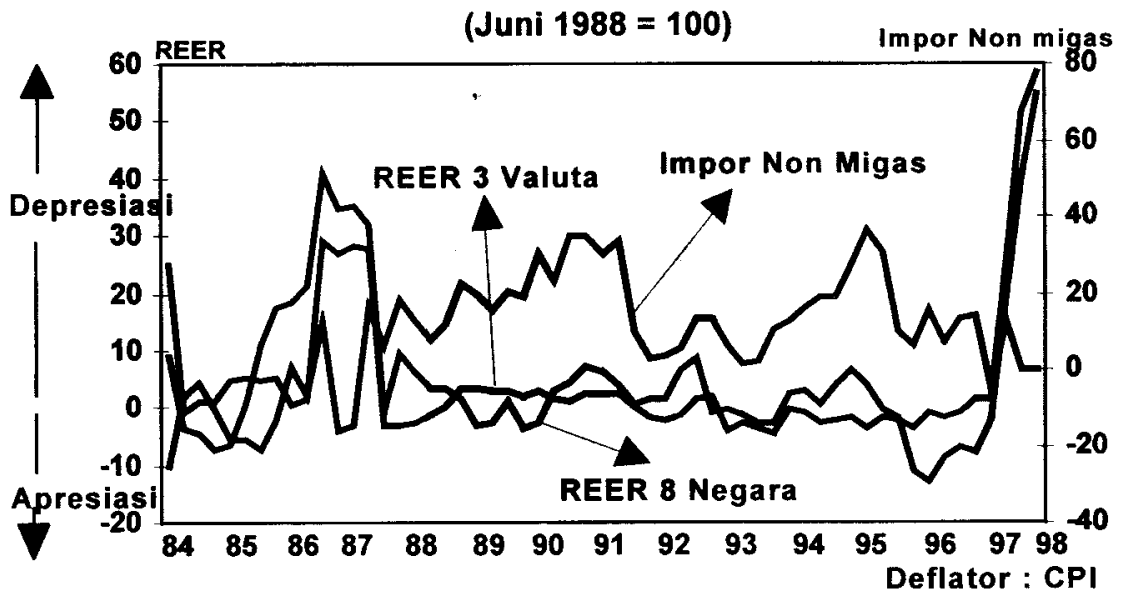

\section{Hubungan Nilai Tukar Dan Inflasi}

Hubungan antara nilai tukar dengan besaran-besaran moneter akan semakin terasa dalam kondisi pesatnya perkembangan valuta asing di dalam negeri. Hal ini merupakan dampak dari tingginya pemasukan dana luar negeri yang relatif tidak terkait dengan kegiatan di sektor riil, tetapi lebih pada pemanfaatan produk-produk di pasar keuangan (dalam bentuk equity dan fixed income papers). Dalam kondisi seperti tersebut di atas, maka nilai tukar riil basket yang lebih apresiatif relatif dibutuhkan dibandingkan kebijakan yang depresiatif dengan pertimbangan beberapa faktor. Pertama, kebijakan yang apresiatif cenderung akan mempengaruhi aggregat moneter dan ekspansi kredit perbankan, sehingga pada akhirnya akan menambah ruang gerak bagi otoritas moneter dalam pengelolaan moneter. Kedua, lebih terkontrolnya aggregat moneter tersebut selanjutnya akan dapat mengurangi tekanan inflasi. Di samping itu apresiasi nilai tukar juga berdampak pada relatif berkurangnya tekanan imported inflation. Selanjutnya perkembangan di atas akan menjaga daya saing ekspor dalam jangka panjang. Ketiga, dengan membiarkan nilai tukar berfluktuasi akan meningkatkan resiko nilai tukar (karena ketidakpastian) yang selanjutnya dapat meredam aliran dana yang bersifat spekulasi.

Hubungan yang searah antara REER dengan tingkat inflasi dapat dilihat pada grafik 13. Pada periode rupiah melemah (depresiasi) cukup besar, tekanan inflasi cenderung juga tinggi. Dan sebaliknya, seperti pada tahun 1996, pada saat rupiah menguat diikuti dengan tingkat inflasi melambat. Kebijakan depresiatif rupiah selama ini cenderung memberikan tekanan inflatoir, meskipun pada periode-periode tertentu kerap terjadi hubungan yang berlawanan antara nilai tukar dengan tekanan inflasi yang terutama berasal dari faktor-faktor lainnya seperti kenaikan administered prices, ataupun gangguan pada supply bahan pangan pokok. 
Grafik 13.

\section{Pertumbuhan Tahunan REER dan Indeks Harga Konsumen}

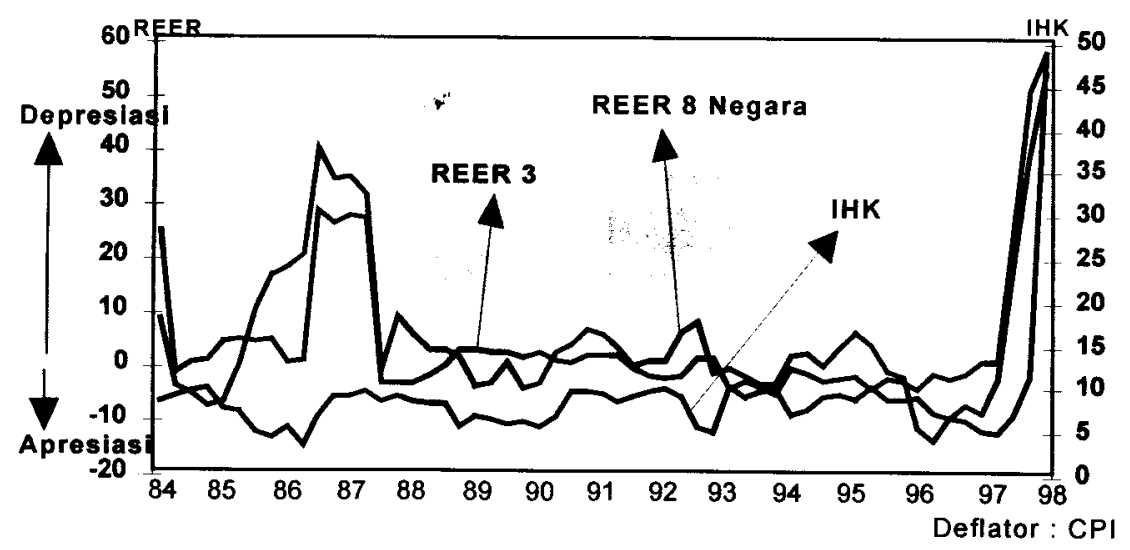

Untuk mengetahui seberapa besar keterkaitan antara REER dan inflasi serta besaran moneter (uang beredar), telah dilakukan uji hubungan antara variabel-variabel tersebut. Hasil temuan sementara yang diperoleh adalah sebagai berikut :

1. Dari hasil Uji Hubungan Granger Causality (tabel 7 dan 8) menunjukkan bahwa (i) selama periode observasi, hanya REER, suku bunga antar bank dan interest rate differential yang mempunyai kausalitas ke arah inflasi dan berarti memiliki daya prediksi yang cukup kuat, (ii) REER mampu menjelaskan perilaku inflasi secara cepat yaitu rata-rata setelah lag 1 triwulan, sementara itu, suku bunga antar bank dan interest rate differential mampu menjelaskan perilaku inflasi tersebut pada periode setelah 2 atau 3 triwulan, (iii) kapasitas produksi sebagai proksi atas supply side rata-rata mempunyai hubungan berlawanan dimana inflasi yang mempunyai hubungan kausalitas terhadap kapasitas produksi, dan bukan sebaliknya. Kondisi ini secara tidak langsung menunjukkan bahwa variabel moneter dan keuangan rata-rata mempunyai predictive power terhadap inflasi lebih kuat dibandingkan variabel dari sisi supply. ${ }^{6}$ Meskipun demikian kapasitas produksi tetap penting dalam menjelaskan perilaku inflasi.

2. Dari hasil Uji Variance Decomposition (tabel 9 dan 10) menunjukkan bahwa (i) REER, suku bunga antar bank dan interest ratedifferential mempunyai predictive power yang relatif kuat dalam menjelaskan error variance inflasi (di luar inflasi itu sendiri) (ii) REER mampu menjelaskan sekitar 1\% (maksimum 7\%) dari error variance ekspor nonmigas pada periode 2 triwulan di muka (observasi 1983.I-1997.II) atau sekitar 4\% (maksimum $21 \%$ ) pada periode 3 triwulan di muka (observasi 1989.I-1997.II), (iii) sekitar 60\% dari error variance inflasi dijelaskan oleh dirinya sendiri, sementara sekitar $13 \%$ dan $7 \%$ dijelaskan masing-masing oleh suku bunga antar bank dan interest rate differential, (iv) variasi CPI dipengaruhi terutama oleh past performance inflasi dan nilai tukar dibandingkan uang beredar, suku bunga, dan output gap, dan (v) dalam jangka yang lebih panjang, pengaruh nilai tukar semakin meningkat dalam menjelaskan variasi CPI. 


\section{Grafik 14. Error Variance Decomposition of CPI Growth 1983.I-1997.II}

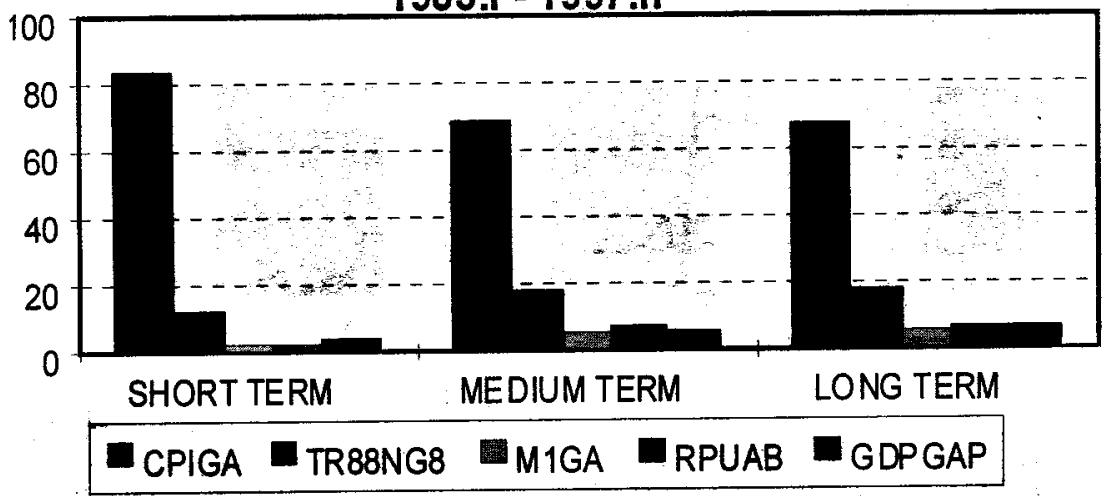

3. Dari hasil Uji Impulse Response Function dari VAR (grafik 15.a dan 15.b) menunjukkan bahwa (i) shocks dari inflasi yang berasal dari suatu perubahan innovation nilai tukar riil pada periode 1983.I-1997.II relatif kecil dibandingkan pada periode 1989.I-1997.II. Hal ini mendukung temuan sebelumnya dimana hubungan nilai tukar dengan inflasi semakin kuat dalam periode capital inflows, (ii) shocks inflasi yang berasal dari suku bunga antar bank, interest rate differential dan uang beredar (M1) di periode capital inflows meskipun tidak sebesar yang berasal dari nilai tukar namun berlangsung panjang.

4. Dari hasil uji regresi terhadap inflasi (CPI) dengan menggunakan variabel nilai tukar riil basket dengan basket 8 negara dan 3 valuta serta tahun dasar Juni 1988 dan 1992=100 (tabel 11) menunjukkan bahwa (i) elastisitas REER terhadap inflasi (CPI) dengan perhitungan basket valuta (sekitar $0,1-0,4)$ lebih besar dibandingkan dengan perhitungan basket negara $(0,1-0,3)$, untuk masing masing tahun dasar, (ii) elastisitas tersebut relatif lebih besar pada periode 1989.I-1997.II (sekitar 0,3-0,4) dibandingkan periode 1983.I1997.II $(0,1)$, (iii) dampak dari perubahan REER terhadap inflasi relatif lebih cepat dirasakan dalam periode 1983.I-1997.II (sekitar 2 triwulan dimuka) dibandingkan periode 1989.I-1997.II (3-9 triwulan di muka), (iv) uang beredar (M1) mempunyai elastisitas sekitar 0,4 terhadap inflasi, sementara itu pengaruh interest rate differential tidak terlalu besar terhadap inflasi (elastisitas relatif kecil sekitar 0,0001\%-0,005\%), karena pengaruh variabel interest rate differential telah tercermin pada variabel uang beredar (M1) ${ }^{7}$, dan (v) kemampuan menjelaskan persamaan inflasi cukup baik yaitu sekitar $99 \%$ dengan standar error of correction sekitar $0,03 \%$.

Dari hasil beberapa pengujian di atas, selanjutnya dapat ditarik beberapa kesimpulan yaitu (i) dengan elastisitas nilai tukar riil terhadap inflasi yang cukup signifikan tersebut, 
maka kebijakan depresiatif rupiah yang dilaksanakan selama ini untuk kepentingan daya saing produk ekspor non migas, relatif mempunyai dampak inflatoir, meskipun tidak segera dan memerlukan time lag yang lebih singkat dibandingkan pada uji ekspor non migas, (ii) pengaruh nilai tukar terhadap inflasi semakin besar dalam periode 8 tahun terakhir (1989.I1997.II), sebagai akibat tingginya kenaikan domestic demand dalam periode tersebut yang pada gilirannya meningkatkan permintaan terhadap impor barang modal dan bahan baku sebagai input produksi, selanjutnya akan memberi tekanan pada tingkat harga (ongkos produksi) setiap kali terjadi perubahan nilai tukar, (iii) seperti pada uji ekspor non migas, nilai tukar riil dengan perhitungan basket valuta lebih sensitif dibandingkan dengan perhitungan basket negara.

\section{Grafluk 15a}

Response to One S.D Innovetlons \& 2 S.E.
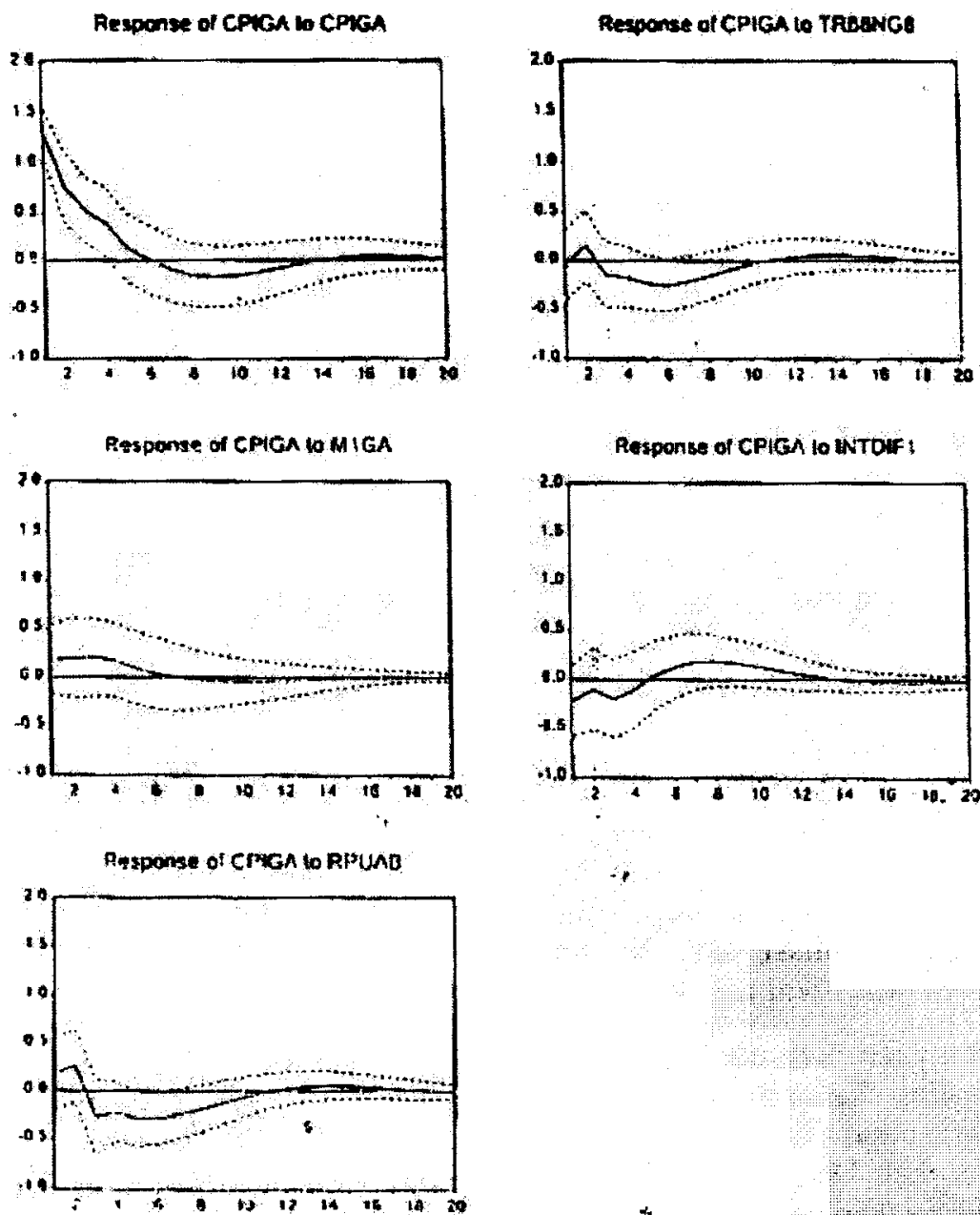

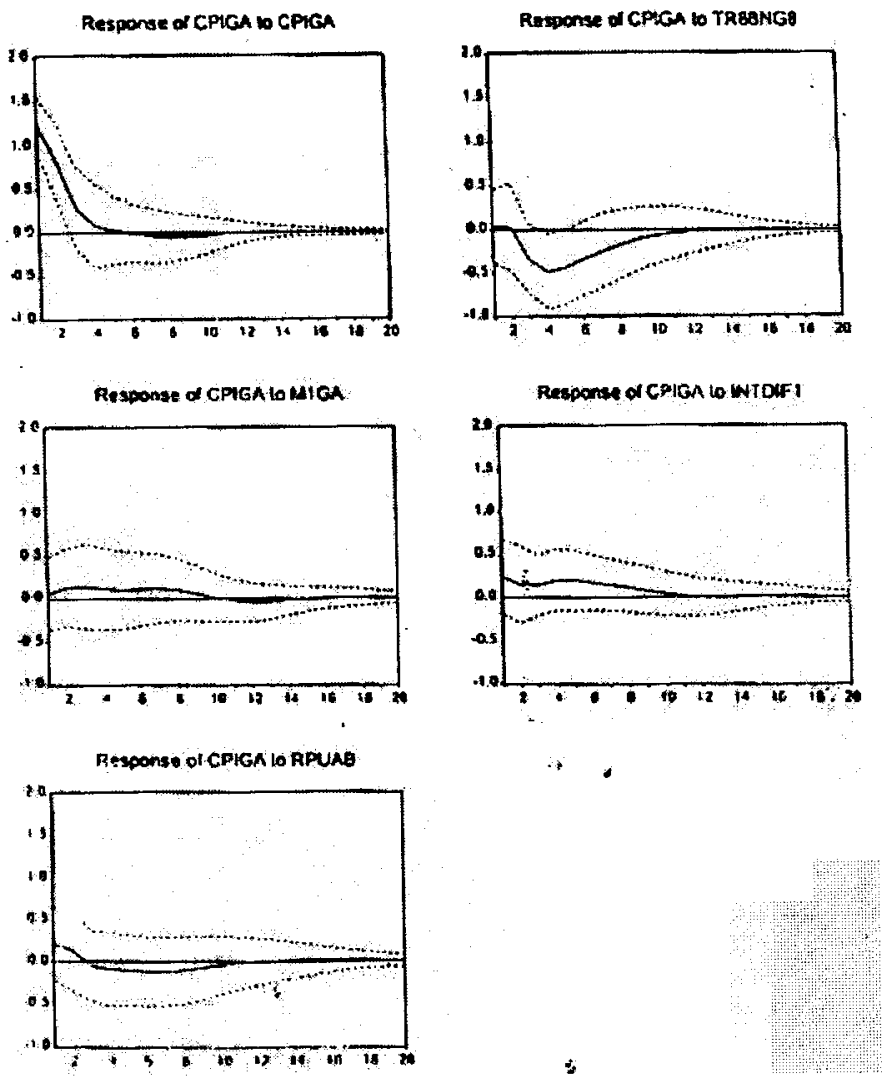

\section{Implikasi Kebijakan}

\section{Trade-off Keseimbangan Internal dan Eksternal}

Kebijakan depresiatif rupiah yang dilakukan selama ini untuk tujuan competitivenes dapat memberi tekanan pada inflasi secara cukup berarti yang pada gilirannya dalam jangka menengah panjang justru akan memukul kembali ekspor (karena kenaikan inflasi domestik akan meningkatkan REER). Demikian pula sebaliknya, jika kebijakan apresiatif seperti yang terjadi di tahun 1996 yang lalu, meskipun competitiveness akan terganggu namun dengan turunnya tekanan inflasi, dalam jangka menengah panjang kembali akan diperbaiki melalui menurunnya nilai tukar riil.

Pertanyaan berikutnya yang berkembang adalah bagaimana dampak perubahan REER terhadap ekspor nonmigas dan tingkat harga dalam jangka pendek dan menengahpanjang serta berapa REER yang "ideal" untuk mencapai target ekspor nonmigas dan inflasi yang diinginkan. Dengan memperhitungkan nilai tukar yang berlaku saat ini, selanjutnya dapat diperkirakan bagaimana dampaknya terhadap ekspor nonmigas dan tingkat inflasi. 

Periode
Nilai Tukar Riil
Dampak I
Dampak II
(Jangka Pendek)
(Jangka Panjang-ceteris paribus)
1983.I-1997.II Depresiasi REER 1\%
(Tw.0)
(Tw.11)

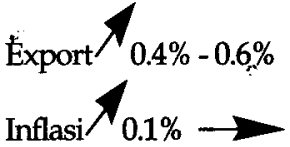
(Tw.2)
Apresiasi $\rightarrow$ Export $0.04 \%-06 \%$
$0,1 \%$
REER
(Tw.13)

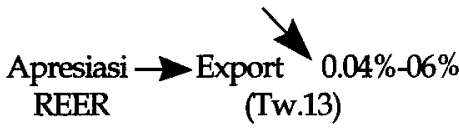
1989.I-1997.II Depresiasi REER 1\%
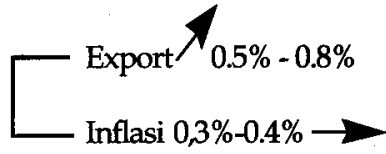
(Tw.3-9)
REER
(Tw.5 - 15)
$0.3 \%-0.4 \%$

Dari skema di atas dapat disimpulkan bahwa peningkatan ekspor sebagai akibat depresiasi REER hanya merupakan fenomena jangka pendek. Dalam jangka menengah panjang, kenaikan harga tersebut, ceteris paribus, akan mengoffset depresiasi REER tersebut yang sëlanjutnya akan melemahkan kembali ekspor.

Dalam rangka mencapai REER yang "ideal", hasilnya sangat tergantung pada berapa besar target ekspor nonmigas dan inflasi yang diinginkan. Untuk memprakirakan keseimbangan nilai tukar tahun 1998, maka digunakan target ideal inflasi tahunan Pelita V maksimal 5\% dan target pertumbuhan ekspor non migas tahun 1998/99 (target RAPBN) minimal sebesar $12 \%$. Selain itu, berbagai asumsi besaran ekonomi yang disepakati antara Indonesia dan IMF diakomodasikan sebagai alternatif target tahun 1998, antara lain inflasi 47\% dan nilai tukar nominal akhir Desember 1998 sebesar Rp.6.000,00/USD. Di dalam perhitungan keseimbangan nilai tukar tahun 1998, inflasi dunia tahun 1998 diasumsikan sebesar 2,2\% (estimasi IMF). Skenario hasil perhitungan dapat dilihat dalam skema di bawah.

a. Untuk mencapai target pertumbuhan 'ekspor non migas tahun 1998 minimal sebesar 12\%, REER harus terdepresiasi minimal sebesar 3\%-4\%. Kenaikan ekspor tersebut baru terjadi pada triwulan 2-6 di muka. Dalam jangka menengah panjang, inflasi akan mencapai 6\% di 3-9 triwulan di muka, yang pada gilirannya, ceteris paribus, akan menyebabkan REER terapresiasi dan selanjutnya pertumbuhan ekspor non migas tertekan, hanya tumbuh $5 \%-7 \%$.

b. Untuk mencapai target inflasi domestik tahunan (Pelita) maksimal sebesar $5 \%$, REER harus terapresiasi minimal sebesar 6\%-7\%. Dampak apresiasi tersebut adalah kenaikan ekspor non migas hanya sebesar 4\%-7,5\% di triwulan 2-6 di muka. Dalam jangka menengah-panjang, sebagai akibat inflasi $5 \%$, ceteris paribus, akan menyebabkan REER terapresiasi dan selanjutnya kembali menekan ekspor non migas hingga hanya tumbuh $6 \%-8 \%$ 


Target $\quad$ Nilai Tukar Ril $\quad \begin{aligned} & \text { Dampak I } \\ & \text { (Jangka Pendek) }\end{aligned}$

Dampak II (Jangka Panjangceteris paribus)

\section{A. Skenario perhitungan sesuai model}

1. Ekspor $\lambda_{12 \%}$ (target APBN)

2 Inflasi $\lambda_{5 \%}$ (target Pelita)

Apresiasi REER $6 \%-7 \%$

Depresiasi REER $84 \%-128 \%$

Depresiasi REER

$3 \%-4 \%$

(Tw.0)

3. Inflasi $\lambda_{47 \%}$ (kesepakatan dng IMF)
Ekspor
(Tw.2-6)

Inflasi $\lambda_{6 \%} \rightarrow$ Apresiasi REER $\rightarrow$ Ekspor $\lambda_{5 \%-7 \%}$ (Tw.3-9) (6\%) (Tw.5-15)

Ekspor $\lambda_{4 \%-7,5 \%}$ (Tw.2-6)

Inflasi $5 \% \rightarrow$ Apresiasi REER $\rightarrow$ Ekspor $\lambda_{6 \%-8 \%}$ (Tw.3-9) (5\%) (Tw.5-15)

Ekspor $>$ 50\%-100\%

(Tw.2-6)

Inflasi $\lambda_{47 \%} \rightarrow$ Apresiasi REER $\rightarrow$ Ekspor $\lambda_{12} \%-24 \%$

(Tw.3-9) (47\%) (Tw.5-15)

B. Skenario perhitungan mixed

4. Nominal Des.98 = Rp.6.000,00/USD dan dan inflasi $47 \%$ (kesepakatan dng IMF)

NEER $\quad=($ Nominal tahun dasar $/$ Nominal Des. 98$)=2.033 / 6000=33,88$

REER 1998-IV = NEER X $(1,47 \times 159,98) /(1,022 \times 110,88)$

REER Des.98 = NEER $\times 235,17 / 113,32$

$=33,88 \times 2,075$

$=70,30$

REER Des.97 $=54,38$

Apresiasi REER $\rightarrow$ Ekspor $3,6 \%-11,58 \%$

29,3\% (Tw.2-6)

c. Untuk mencapai target inflasi domestik tahun 1998 maksimal sebesar $47 \%$, REER terdepresiasi sebesar $84 \%-128 \%$. Dampak depresiasi tersebut adalah kenaikan ekspor non migas sebesar 50\%-100\% di triwulan 2-6 di muka. Dalam jangka menengah panjang, sebagai akibat inflasi $47 \%$, ceteris paribus, akan menyebabkan REER terapresiasi $47 \%$, dan selanjutnya akan menekan ekspor non migas hingga hanya tumbuh $12 \%-24 \%$.

d. Untuk mencapai target nilai tukar nominal sebesar Rp.6.000,00/USD dan inflasi sebesar 47\% pada akhir Desember 1998, maka REER harus terapresiasi sebesar $29,3 \%$, dan selanjutnya akan mengakibatkan ekspor non migas menurun sebesar 3,6\%-11,58\%. 


\section{Target Nilai Tukar Riil dan Implikasi Kebijakan}

\section{REER Targeting}

Dengan mengamati berbagai skenario tersebut di atas, secara umum dapat dikemukakan bahwa kebijakan nilai tukar "idealnya" diarahkan untuk mencapai suatu target nilai tukar riil yang ditujukan pada pencapaian inflasi dan atau ekspor non migas. Pemilihan target nilai tukar secara riil dibandingkan nominal adalah mengingat pendekatan riil lebih mencerminkan kekuatan nilai mata uang yang sebenarnya (yaitu setelah mempertimbangkan tingkat harga relatif).

Dalam melakukan analisa terhadap target nilai tukar riil untuk tahun 1998, maka pengamatan perkembangan REER tersebut akan difokuskan pada paruh kedua tahun 1997. Krisis nilai tukar yang melanda Indonesia, yang diperparah dengan terjadinya krisis kepercayaan terhadap perbankan dan belum tuntasnya penyelesaian masalah utang luar negeri sektor swasta, telah menyebabkan Rupiah terdepresiasi cukup besar (lihat grafik 16). Namun demikian, perkembangan REER tersebut relatif tidak lagi mencerminkan perkembangan fundamental perekonomian dan lebih dipengaruhi oleh faktor non ekonomi, terutama setelah keputusan pemerintah untuk melepas band intervensi pada bulan Agustus 1997. Dalam kaitan ini, maka untuk memperoleh nilai tukar riil yang lebih mencerminkan kondisi rii perekonomian, maka sejak paruh kedua 1997 digunakan pendekatan NATREX atau Natural Real Exchange Rate, dan selanjutnya digunakan sebagai target nilai tukar untuk tahun 1998.

\section{Natural Real Exchange Rate (NATREX)}

Untuk memperkirakan keseimbangan nilai tukar riil tahun 1998, model regresi nilai tukar di atas belum memberikan hasil yang representatif, karena dalam periode nilai tukar

\section{Grafik 16. Perkembangan REER tahun 1997}

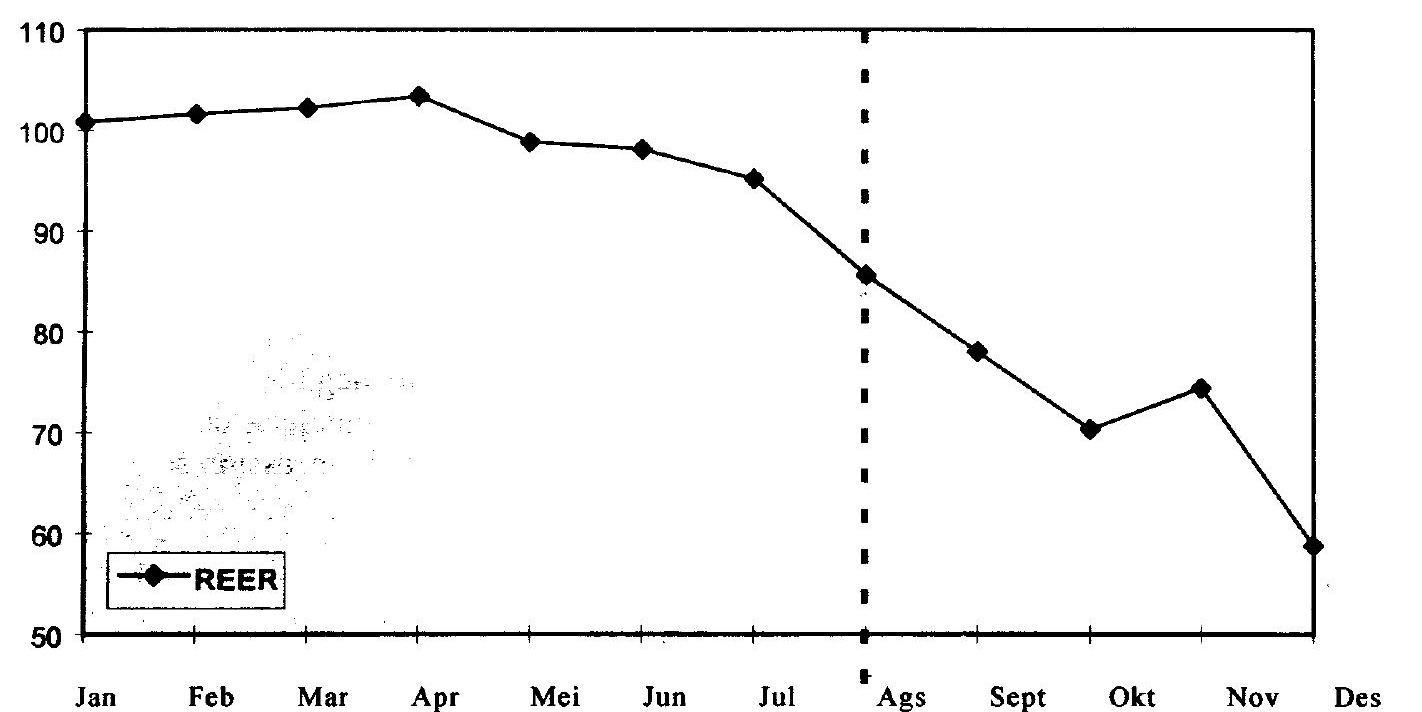




\section{Grafik 17 Perkembangan Natrex dan REER}

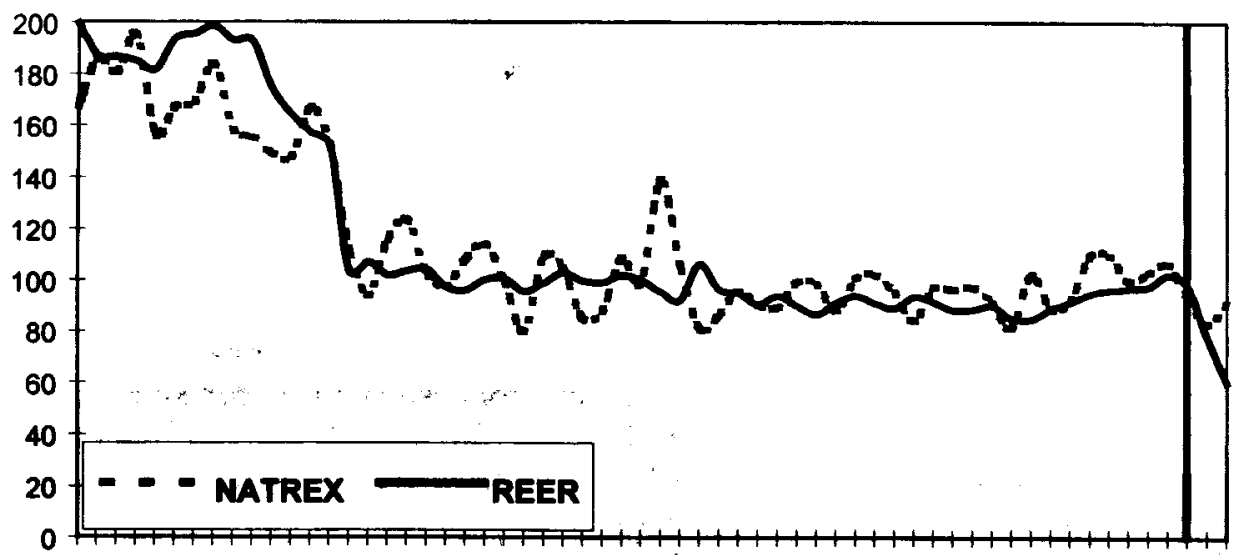

$\begin{array}{lllllllllllllll}1983 & 1984 & 1985 & 1986 & 1987 & 1988 & 1989 & 1990 & 1991 & 1992 & 1993 & 1994 & 1995 & 1996 & 1997\end{array}$

fleksibel (free floating), penjelasan sistematik tentang pergerakan nilai tukar jangka pendek menjadi sulit dipahami akibat adanya pengaruh dominasi spekulasi aliran modal dan estimasi aliran. Oleh karena itu, untuk memenuhi kebutuhan proyeksi, perlu dilengkapi dengan alternatif pendekatan nilai tukar riil lainnya. Dalam hubungan ini, model keseimbangan nilai tukar riil jangka menengah (inter-cyclical equilibrium real exchange rate) NATREX (Natural Real Exchange Rate) merupakan salah satu alternatif yang dapat digunakan. Bukti empiris di Australia dan Amerika Latin menunjukkan bahwa nilai tukar riil menyesuaikan lebih cepat ke arah NATREX, tanpa bukti overshooting, sehingga fundamental lebih mampu menjelaskan nilai tukar riil, saat nilai tukar nominal adalah fleksibel. Pendekatan ini lebih memusatkan perhatian pada faktor fundamental riil dalam menjelaskan variasi nilai tukar riil, tanpa memperhitungkan faktor siklikal, spekulasi aliran modal, dan pergerakan cadangan devisa.

Hasil perhitungan NATREX di Indonesia menunjukkan bahwa dalam jangka panjang (1983-1997), beberapa variabel fundamental secara bersama-sama signifikan mempengaruhi nilai tukar riil di Indonesia, dengan rincian (i) terms of trade secara statistik signifikan berpengaruh positif terhadap REER, dengan koefisien elastisitas sebesar 1,25, (ii) produktivitas secara statistik signifikan berpengaruh negatif terhadap REER, dengan koefisien elastisitas sebesar 0,117, (iii) rasio tabungan terhadap PDB secara statistik signifikan berpengaruh negatif terhadap REER, dengan koefisien elatisitas sebesar 0,026, (iv) rasio perbedaan suku bunga secara statistik signifikan berpengaruh negatif terhadap REER, dengan koefisien elastisitas sebesar 0,015, dan (v) kemampuan menjelaskan persamaan NATREX cukup baik yaitu sekitar 80,7\%, dengan standar error of regression sekitar 0,12 .

Dari grafik 17 terlihat bahwa dalam jangka panjang, trend pergerakan NATREX dan REER relatif sama. Namun dalam penggalan-penggalan waktu yang lebih pendek tampak adanya perbedaan arah antara NATREX dan REER, yang berarti faktor non fundamental ikut berperan mempengaruhi pergerakan nilai tukar riil (REER). Dalam periode free floating, krisis keuangan yang melanda Asia sejak triwulan II 1997 memberikan contagion effect 
kepada Indonesia, tercermin dari melebarnya perbedaan NATREX terhadap REER sejak memasuki triwulan III 1997.

\section{Target Nilai Tukar Riil Tahun 1998}

Bertitik tolak dari kenyataan di atas, maka untuk memenuhi kebutuhan proyeksi tahun 1998, posisi NATREX triwulan IV 1997 (menggantikan REER triwulan IV 1997) dapat digunakan sebagai titik awal penentuan target nilai tukar riil untuk triwulan IV 1998. Grafik 18 dan 19 menggambarkan skenario proyeksi NATREX tahun 1998 berdasarkan alternatif target ekspor non migas dalam APBN (12\%) dan target inflasi dalam Pelita (5\%). Grafik tersebut juga menampilkan perkiraan nilai tukar riil 1998 berdasarkan perhitungan model NATREX. Dengan disertai beberapa asumsi tentang TOT 1998 (relatif sama dengan tahun 1997), rasio tabungan terhadap PDB 1998 (20\%), produktivitas ekonomi 1998 (menurun 1,6\% dibanding tahun 1997), dan perbedaan suku bunga tahun 1998 (25\%), maka proyeksi pertumbuhan NATREX tahun 1998 diperkirakan sebesar 17.3 \% (apresiasi).

Implikasi Kebijakan

Dengan mengamati skenario perkembangan dan pertumbuhan NATREX dan dikaitkan dengan proyeksi NATREX, maka secara garis besar ada tiga implikasi kebijakan yang bisa disarikan yaitu :

1. Kebijakan depresiatif nilai tukar riil yang ditujukan untuk mendorong ekspor non migas cenderung berdampak inflatoir. Seandainya fokus utama otoritas moneter adalah untuk tujuan daya saing, maka perkembangan nilai tukar akhir-akhir ini tidak perlu

Grafik 18. Skenario REER Dan NATREX Berdasarkan Alternatif Target 1998

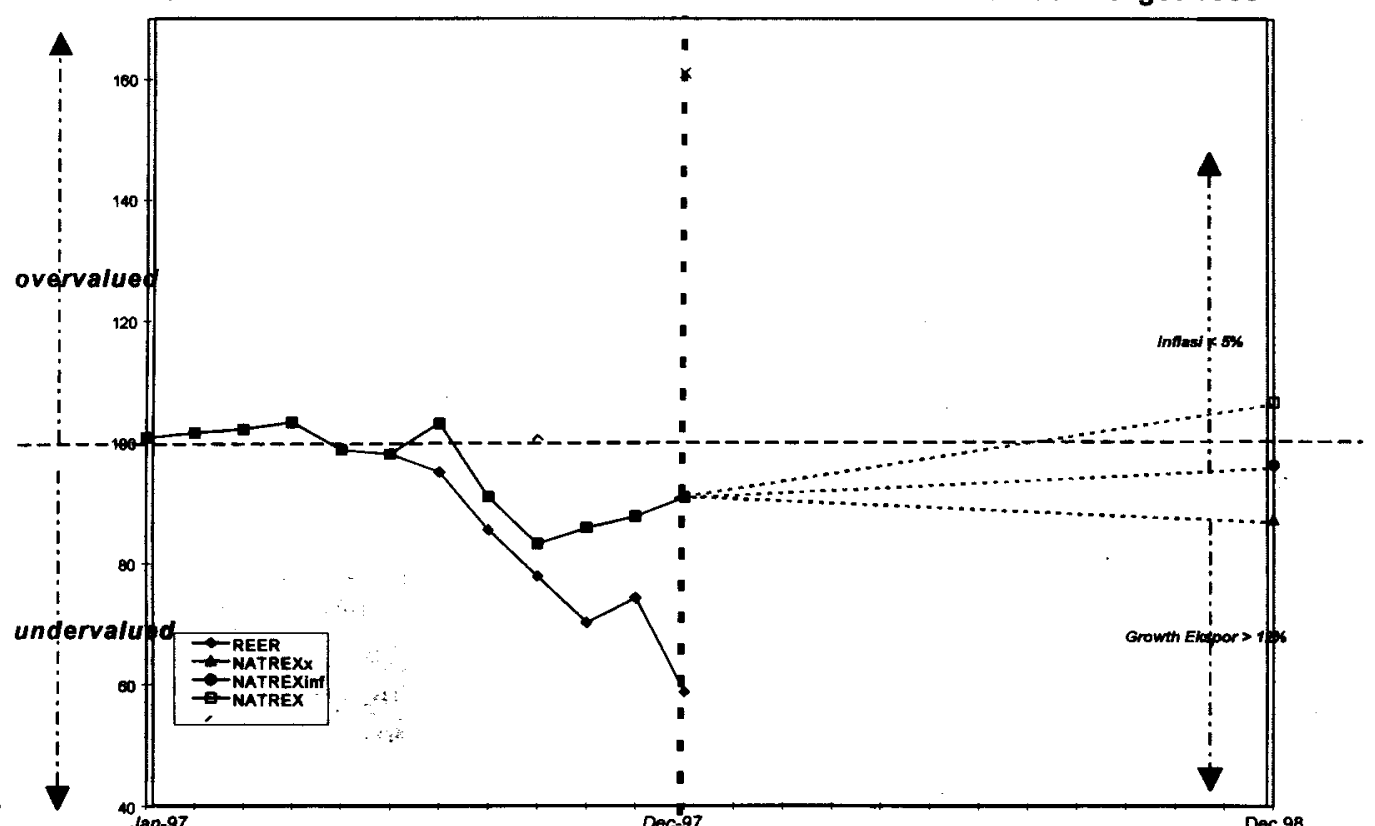




\section{Grafik 19. Skenario Pertumbuhan NATREX Berdasarkan Alternatif Target 1998}

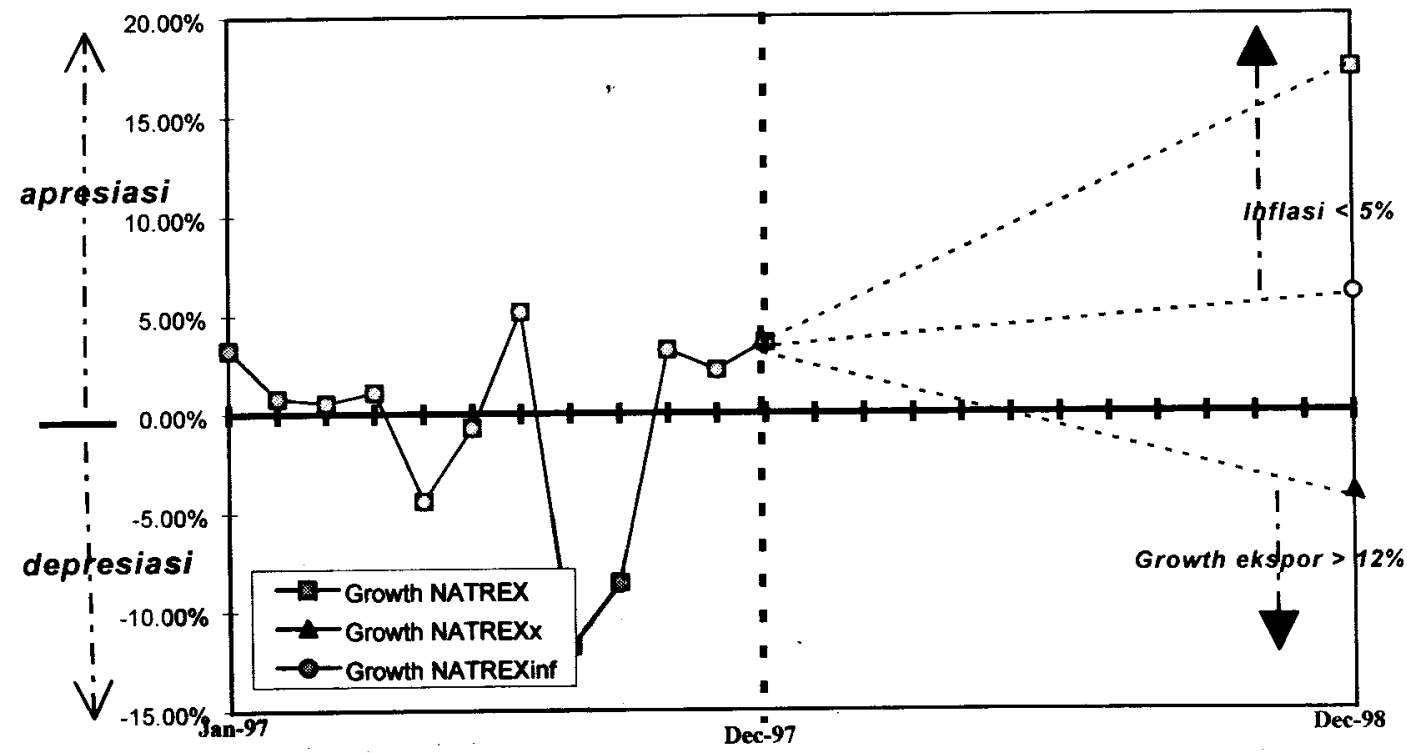

dikhawatirkan, bahkan kalau perlu depresiasi terus dipercepat. Sekali lagi disini, dampak inflatoir harus dikesampingkan.

2. Kebijakan apresiatif nilai tukar riil yang ditujukan untuk mengurangi tekanan inflasi dapat berpengaruh negatif pada daya saing. Seandainya tujuan utama otoritas moneter adalah kestabilan harga, maka Bank Indonesia melalui kebijakan makro ekonomi yang ditujukan terhadap nilai tukar, harus mengarahkan nilai tukar ke tingkat depresiasi yang lebih kecil atau bahkan apresiasi. Dalam kondisi ini, tentunya pilihan terhadap daya saing harus dinomorduakan.

3. Dalam era free floating, hasil perhitungan model NATREX menunjukkan adanya dorongan apresiatif nilai tukar riil pada tahun 1998, yang berarti tuntutan untuk kestabilan harga perlu mendapat perhatian utama dari pengelola kebijakan moneter. Walaupun kajian NATREX dalam penelitian ini tidak melihat langsung kaitan antara NATREX dengan ekspor ataupun inflasi, namun secara teoritis dapat dikemukakan bahwa nilai tukar riil Rupiah (NATREX) yang undervalued sejak triwulan III 1997, di satu sisi mendorong daya saing ekspor, sementara di sisi lain mengandung dampak inflatoir.

Dari implikasi pertama dan kedua, tampaknya trade off harus dilakukan oleh otoritas moneter dalam mencapai kedua target itu. Bahwa kebijakan nilai tukar selama ini diarahkan untuk menjaga keseimbangan internal dan eksternal menurut hasil studi sulit mencapai hasil maksimal. Pertumbuhan ekspor non migas yang lebih rendah atau tingkat inflasi yang lebih tinggi dari target yang diinginkan adalah kemungkinan yang dapat terjadi dari penerapan kebijakan tersebut. Implikasi ketiga secara spesifik lebih mempertegas prioritas utama kebijakan nilai tukar riil pada tahun 1998 adalah apresiatif, dalam arti mengangkat nilai tukar riil ke posisi yang lebih menjamin tercapainya stabilitas nilai tukar rupiah dan harga-harga. 
Bertolak dari kondisi di atas, pada dasarnya trade off tersebut dapat dikurangi, seandainya kita mampu mengurangi sensitivitas nilai tukar terhadap ekspor non migas dan inflasi. Untuk itu ada dua langkah yang dapat dilakukan, yaitu :

1. Mengurangi peranan nilai tukar sebăgai salah satu pendorong utama kinerja ekspor. Hasil studi menunjukkan bahwa meskipun sensitivitas tersebut cukup tinggi, namun pengaruh nilai tukar, atau ekspor non migas bersifat tidak segera dan relatif singkat. Hal ini sesuai dengan studi yang dilakukan oleh Anwar Nasution (199.) yang menyatakan bahwa J-Curve untuk Indonesia berlangsung pendek. Artinya bahwa devaluasi/ depresiasi rupiah hanya akan mengurangi defisit transaksi berjalan dalam periode yang pendek, dan selanjutnya defisit tersebut kembali membesar. Dalam hal ini, langkah utama yang harus ditempuh pemerintah adalah bagaimana meningkatkan sisi supply dari ekspor, dan untuk kebijakan moneter/nilai tukar bukanlah menjadi kebijakan utama, tetapi justru kebijakan di sektor riil seperti deregulasi di sektor industri, perdagangan, pelabuhan dan lain-lain, yang harus diandalkan.

2. Mengurangi pengaruh nilai tukar pada pembentukan tingkat harga, atau imported inflation. Dan ini berarti bagaimana mengurangi import content atau meningkatkan local content pada struktur industri.Sekali lagi kebijakan di sektor riil adalah yang paling signifikan ditempuh dalam kondisi tersebut daripada kebijakan moneter/nilai tukar.

Dalam kaitan ini, apabila alternatif pertamayang dipilih, maka otoritas moneter dapat lebih memfokuskan kebijakan nilai tukar atau kebijakan moneter yang diarahkan pada nilai tukar untuk kestabilan harga. Dan sebaliknya jika alternatif kedua yang dipilih, maka kebijakan tersebut dapat difokuskan pada daya saing. Dengan mengamati sensitivitas nilai tukar terhadap ekspor yang lebih besar dibandingan terhadap inflasi, maka alternatif pertama relatif yang paling relevan dibandingkan alternatif kedua. Kebijakan moneter seyogyanya hanya menjadi pelengkap dari kebijakan sektor riil dalam upaya meningkatkan kinerja ekspor non migas. Kebijakan di sektor riil tersebut relatif akan berdampak positif pada peningkatan ekspor non migas dalam periode yang bersifat jangka panjang, dibandingkan mengandalkan kebijakan nilai tukar. Sudah saatnya otoritas moneter kini memfokuskan tugasnya lebih pada kestabilan harga dibandingkan pada peningkatan ekspor.

\section{Pengendalian Nilai Tukar Dalam Era Free Floating}

Dalam mencapai target nilai tukar riil seperti diulas diatas, maka pergerakan nilai tukar nominal relatif harus diarahkan untuk mencapai kondisi tersebut. Prasyarat ini sangat sulit tercapai setelah otoritas moneter melepas penetapan nilai tukar sepenuhnya ke pasar. Dalam kaitan ini, maka perlu dipertimbangkan kembali sistem free floating dalam kebijakan nilai tukar di Indonesia.

Dari hasil temuan empiris Bagian SEI/UREM (1998) ${ }^{8}$ menunjukkan bahwa variasi inflasi di Indonesia yang dijelaskan oleh shocks nilai tukar meningkat pada kurun waktu triwulan III 1997 - triwulan I 1998. Hasil temuan juga menunjukkan bahwa fleksibilitas 
Rupiah cenderung memberikan variasi yang lebih kecil pada perkembangan variabelvariabel moneter utama yaitu uang primer dan suku bunga. Begitu pula variasi uang primer dan suku bunga yang dijelaskan oleh shocks nilai tukar pada periode free floating menurun secara signifikan, yang pada gilirannya akan mempengaruhi aliran modal. Selanjutnya, nilai tukar yang semakin fleksibel cenderung akan mendorong competitiveness yang lebih besar, sejalan dengan kecenderungan depresiasi yang lebih besar.

Dari analisa tersebut maka diperoleh kesimpulan sementara bahwa Indonesia dihadapkan pada masalah trade off antara kebutuhan fleksibilitas nilai tukar Rupiah dan kebutuhan stabilitas harga. Dengan struktur perekonomian Indonesia saat ini dimana stabilitas harga masih belum terjamin dan external shock semakin besar, maka fleksibilitas nilai tukar secara bertahap merupakan pilihan terbaik. Tindakan melepas secara mendadak keseimbangan nilai tukar ke pasar, khususnya dalam masa krisis menimbulkan volatilitas Rupiah dan lonjakan inflasi yang sulit dikendalikan. Oleh karena itu, pengelolaan sistem nilai tukar yang mengkombinasikan antara unsur floating dan managed merupakan alternatif jalan keluar yang dinilai layak untuk dikaji kembali. Dalam kaitan ini, untuk mengarahkan nilai tukar nominal ke level yang diinginkan, maka peranan intervensi otoritas moneter masih sangat diperlukan selama sistem band tidak lagi digunakan.

Dalam rangka mengurangi volatilitas Rupiah, intervensi bank sentral menjadi bagian penting dari sistem pure/free floating dalam mengarahkan Rupiah ke true long-run equilibrium level yang mencerminkan kondisi fundamental. Secara teoritis, ada dua hal yang perlu diperhatikan oleh bank sentral dalam melakukan intervensi yaitu timing dan sifat intervensi. Dari faktor timing, intervensi perlu melihat critical time dari pergerakan nilai tukar untuk memutuskan saat yang tepat untuk melakukannya. Pada saat sentimen pasar sangat kuat dan unsur spekulasi dominan di pasar - pasar yakin dengan gerakan nilai tukar - intervensi relatif tidak akan efektif karena tidak mampu mengimbangi jumlah transaksi harian di pasar valas yang sangat besar. Intervensi relatif hanya akan membuang devisa tanpa hasil maksimal. Sebaliknya pada saat kondisi normal, dimana sentimen pasar tidak kuat, intervensi dalam jumlah kecilpun akan mampu mempengaruhi undesirable movement dari nilai tukar. Dikaitkan dengan timing, maka faktor kedua yang harus diperhatikan yaitu sifat intervensi, yaitu bersifat direct dan indirect (Michael R. Rosenberg, 1996). Direct intervention lebih melihat volume dan intensitas intervensi dalam mempengaruhi undesirable movement dan upaya ini relatif efektif dalam situasi pasar valas yang normal. Sementara itu indirect investment lebih mementingkan market response dari intervensi tersebut dan bagaimana ekspektasi pasar dapat diperbaiki, sehingga intervensi ini akan efektif dalam kondisi pasar valas yang tidak normal. Dalam hal ini intervensi hanya merupakan signal ke pasar sehingga tidak perlu dilakukan dalam jumlah besar. Untuk itu bank sentral perlu memiliki Market Intelligence Unit agar dapat memantau dan melakukan kontak dengan pelaku pasar secara kontinyu. Di samping itu perlu pula dilakukan kajian mendalam untuk menetapkan batas acuan dalam intervensi, seperti penetapan hidden atau unpublished band. Tidak ketinggalan pelaksanaan economic structural reforms harus terus dilanjutkan dalam rangka memulihkan kepercayaan pasar.

\section{Kesimpulan}

1. Hasil empiris menunjukkan bahwa nilai tukar riil mempunyai elastisitas yang cukup besar terhadap ekspor non migas (meskipun dengan time lag) dan relatif kecil terhadap 
CPI. Pencapaian keseimbangan internal (CPI) dan eksternal (ekspor non migas) tidak dapat dilakukan bersama. Trade-off harus ditempuh untuk mengoptimalkan sasaran, kecuali dilakukan pengurangan elastisitas nilai tukar terhadap ekspor non migas (dengan' cara meningkatkan kualitas produk ekspor) dan pengurangan elastisitas nilai tukar terhadap CPI (dengan cara mengurangi import content produk).

2. Kebijakan nilai tukar diarahkan pada pencapaian target riil. Akibat adanya krisis, fluktuasi nilai tukar riil (REER) semakin sulit diterjemahkan oleh determinan ekonomi, sehingga perlu dicari alternatif pembanding lain yang lebih mencerminkan kondisi fundamental perekonomian. NATREX (Natural Real Exchange Rate), sebagai suatu pendekatan alternatif keseimbangan nilai tukar riil jangka menengah (inter-cyclical equilibrium real exchange rate) menunjukkan bahwa dalam era free floating, terjadi perbedaan arah antara NATREX dan REER, yang berarti faktor non fundamental mempengaruhi pergerakan nilai tukar riil (REER). Untuk tahun 1998 nilai tukar riil (NATREX) terapresiasi, dengan kata lain tuntutan kestabilan harga perlu mendapat perhatian utama dari pengelola kebijakan.

3. Pengelolaan sistem nilai tukar fleksibel (free floating) terbukti dapat mendukung pengendalian moneter dan daya saing, tetapi di sisi lain menyulitkan pencapaian stabilitas harga selama import content dalam struktur industri di dalam negeri masih tinggi. Sepanjang target atau sasaran akhir pengendalian moneter adalah kestabilan harga (asumsi single target), maka penetapan sistem kombinasi antara nilai tukar tetap dan free floating adalah yang paling tepat. Dengan kata lain, pengelolaan sistem nilai tukar fleksibel terkendali (managed floating) merupakan alternatif jalan keluar yang dinilai layak untuk dikaji kembali. Apabila sampai sejauh ini band nilai tukar masih "belum layak" diterapkan kembali, maka intervensi otoritas moneter secara berkala ke pasar dinilai perlu, dengan memperhatikan faktor ketepatan timing, sifat, dan batas acuan intervensi yang didukung oleh keberadaan Market Intelligence Unit.

4. Dalam rangka meredam gejolak nilai tukar dan mempercepat proses exit dari krisis, disamping kebijakan moneter dan nilai tukar, kebijakan susulan seperti kebijakan fiskal, restrukturisasi sektor keuangan dan reformasi struktur ekonomi (economic structural reform) sangat dibutuhkan. Pelaksanaan reformasi secara integral dan konsisten adalah kunci utama ke arah perbaikan kredibilitas pemerintah di dalam dan luar negeri. 







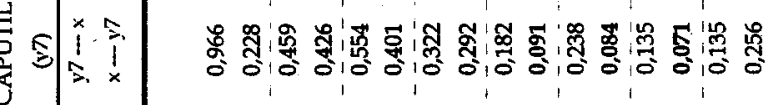

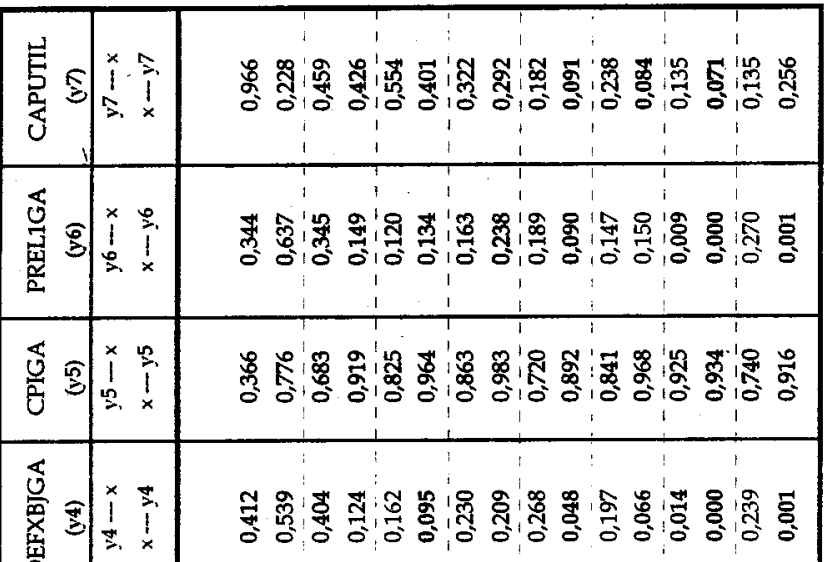

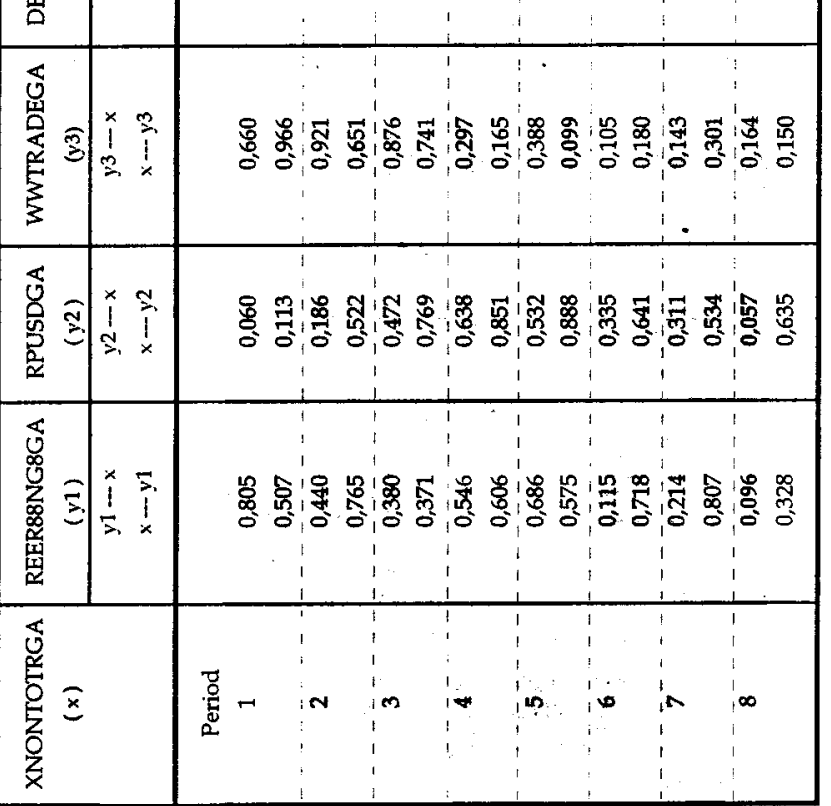






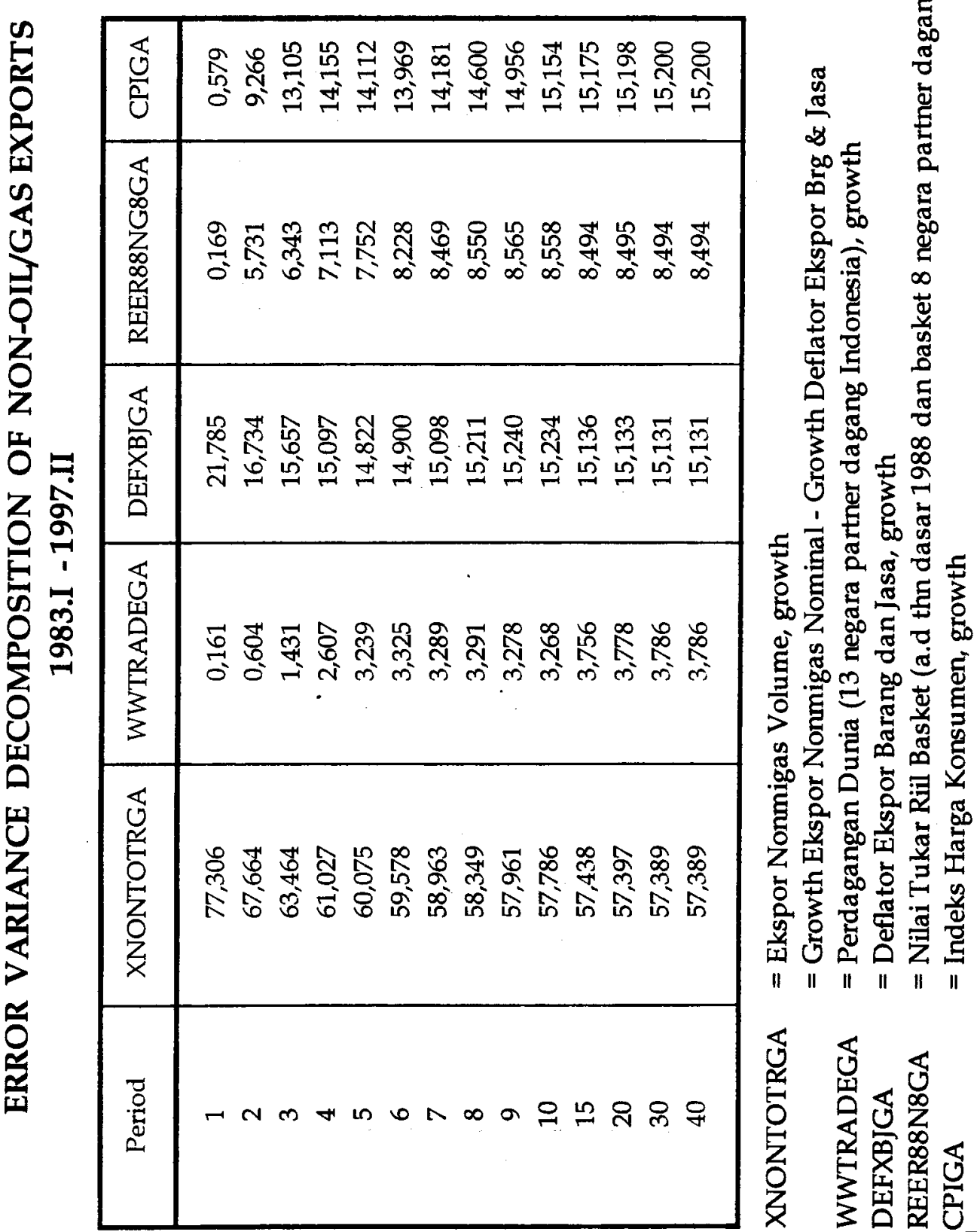




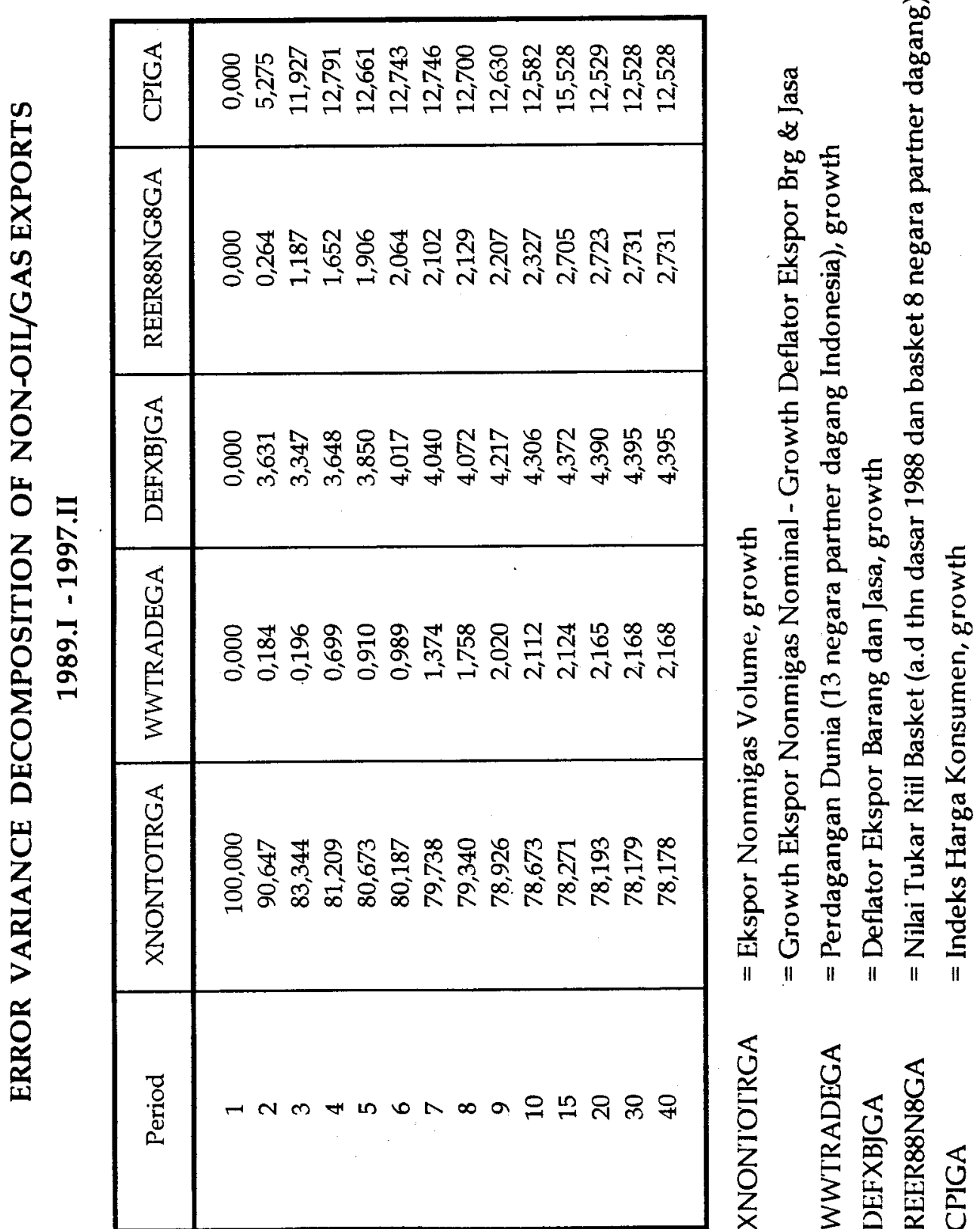




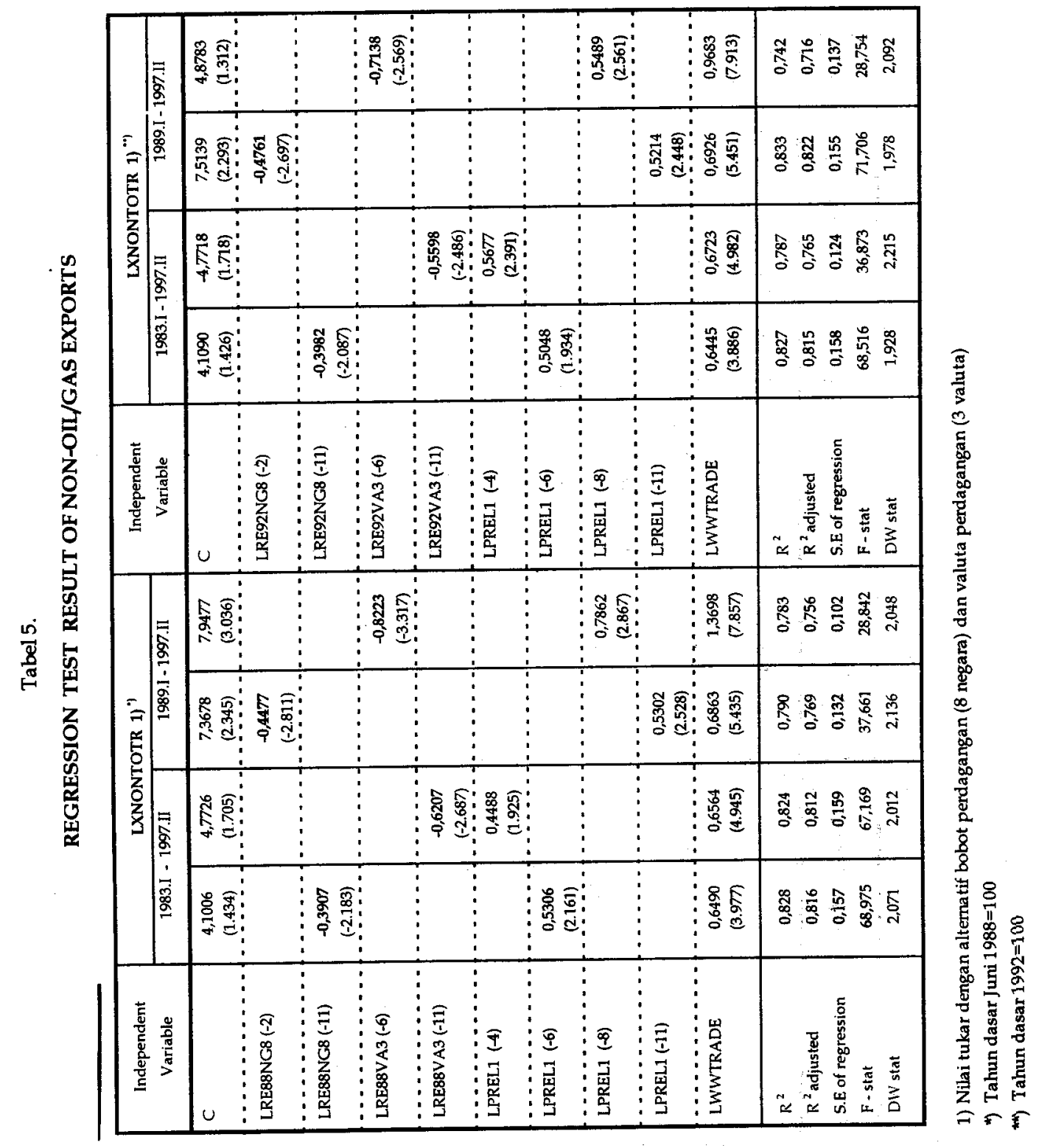









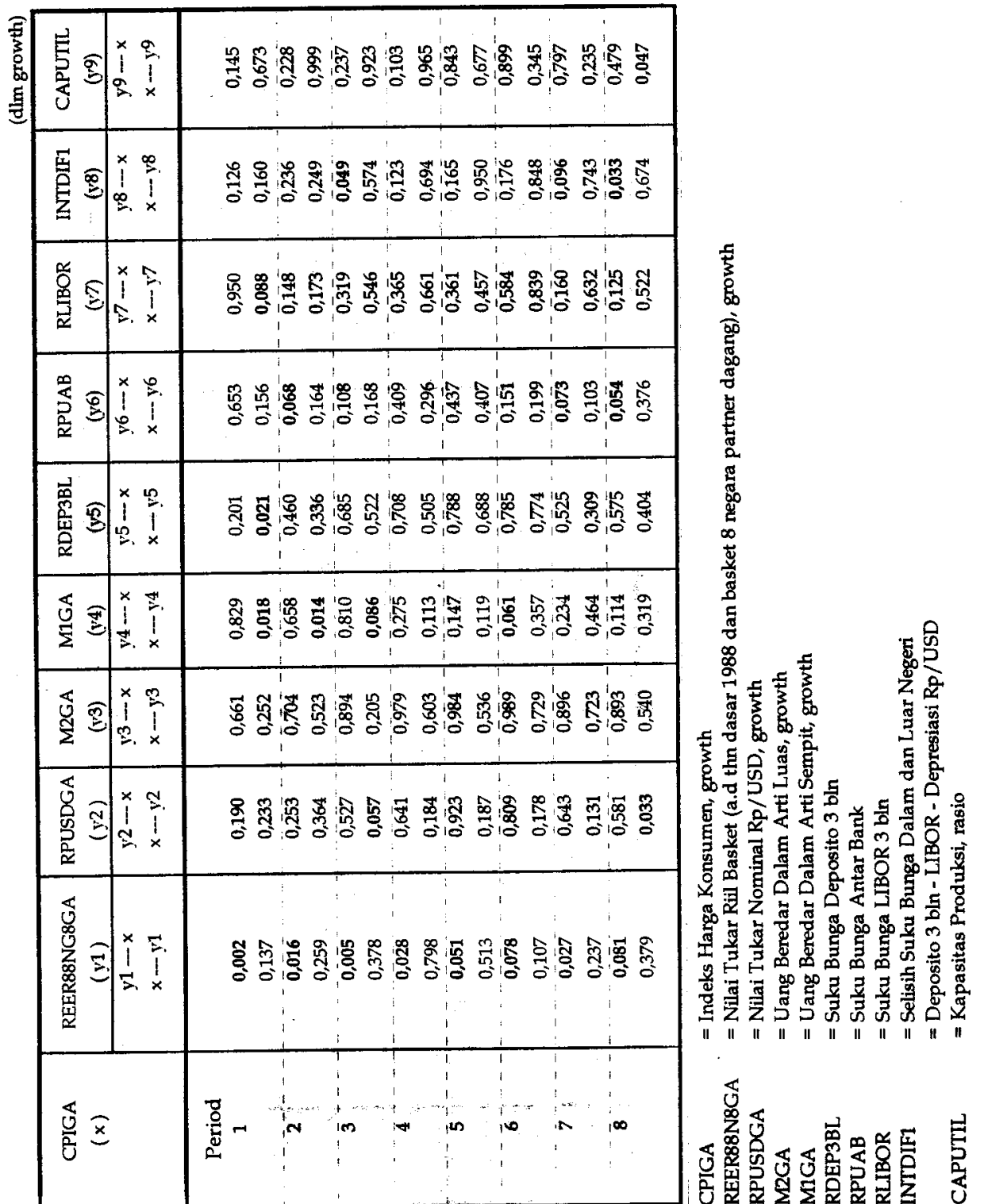







122 Buletin Ekonomi Moneter dan Perbankan, Juli 1998

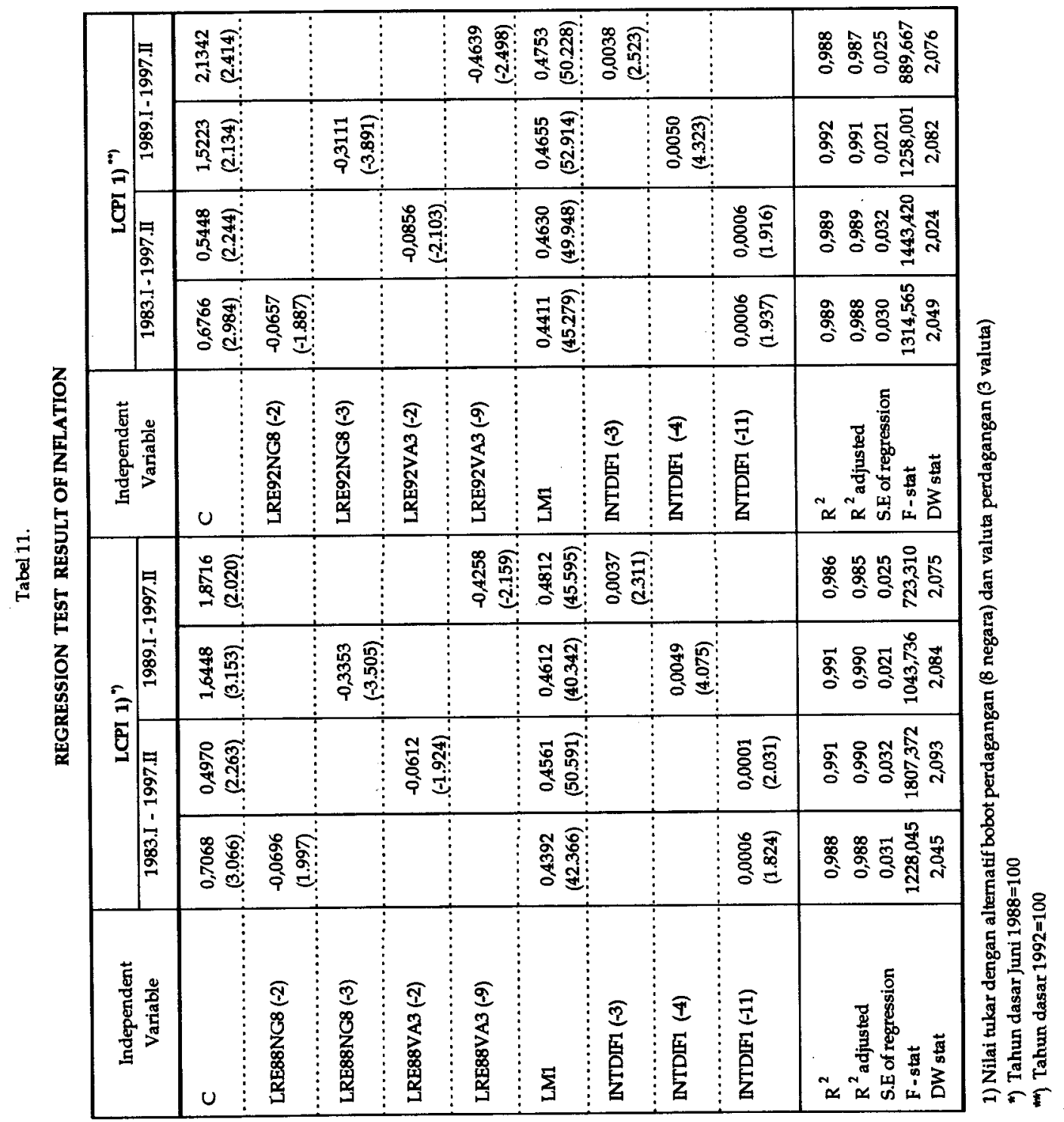

